\title{
Hydrogeochemical Variations of Groundwater of the Northern Jabal Hafit in Eastern Part of Abu Dhabi Emirate, United Arab Emirates (UAE)
}

\author{
Ahmed Murad $^{1 *}$, Faris Mahgoub ${ }^{2}$, Saber Hussein ${ }^{1}$ \\ ${ }^{1}$ Department of Geology, UAE University, Al-Ain, UAE \\ ${ }^{2}$ WJ Groundwater Ltd., Dubai/Jumierah Lakes Towers, Dubai, UAE \\ Email: $\left\{{ }^{*}\right.$ ahmed.murad, s_hussein $\} @$ uaeu.ac.ae, faris_mirghani@hotmail.com
}

Received March 16, 2011; revised January 27, 2012; accepted March 2, 2012

\begin{abstract}
This study is aimed to assess and evaluate the suitability of groundwater of the area located to the south-east of Al-Ain area in the UAE using hydrogeochemcical approach. The chemical analyses of groundwater samples collected from the study area showed that the groundwater salinity is high which resulted from heavy groundwater pumping. High chloride concentrations in groundwater of Mubazarah and Neima might be attributed to the entrapped saline water within the limestone sequence of Jabal Hafit, or it can be the agricultural activities as it clear from the positive relationship between $\mathrm{Cl}^{-}$and $\mathrm{Br}^{-}$. High sulphate concentrations in groundwater might be related to the presence of gypsum and anhydrite within the limestone sequence of Jabal Hafit. The anionic and cationic compositions of groundwater indicate that the chloride and sodium ions are the dominant and presence of bicarbonate and sulphate may reflect the mixing of such water by the recent freshwater through the existing structural lineaments within the study area. The hydrochemical parameters indicate a relative increase in the concentration of calcium, magnesium and sulphate ions and this could reflect the influence of carbonates and evaporite sediments.
\end{abstract}

Keywords: United Arab Emirates; Salinity; Major Cations and Anions; Groundwater; Water Genesis

\section{Introduction}

The study area is located within the vicinity of Al-Ain region in which the climate is deficient in rainfall, with a mean annual rainfall of about 96.4 millimeters [1]. AlAin area is considered to be a better ephemeral surface water resource in the country due to the occurrence of flash floods. Ain Al-Faydah (Ain Bu Sukhanah) is the only spring with Al-Ain area, which is located about 15 $\mathrm{Km}$ south of Al-Ain and about $2 \mathrm{~km}$ west of Jabal Hafit. According to El-Shami [2], the spring produces from Miocene gypsum and clay layers through thin Quaternary loose sediments. The spring represents the discharge area of a deep water source which finds its way up through one of several thrust faults dissecting the area.

The aquifer in the area is recharged by the infiltration of the precipitation in the interdune areas and gravel plains and also from Jabal Hafit. Another source of recharge includes irrigation water, upward vertical recharge from deeper rocks and infiltration of water lost from the leaky water transmission lines [3].

The domestic water requirements in the region were met from major aquifers. However, massive increases in

"Corresponding author. domestic demands due to the annual population growth rate of up to $8 \%$ [4] has meant that groundwater resources have been placed under increasing stress, resulting in declining water levels, and increasing groundwater salinity and a resultant decrease in total production.

The widening gap between groundwater supply and domestic demand has been met from an expansionist policy of desalination using all types of production process under an ever increasing responsibility of the private sector. In 2003, the total domestic wellfield production in Abu Dhabi Emirate had reduced to only $26 \mathrm{Mm}^{3} / \mathrm{yr}$, meeting only $17 \%$ of the total domestic requirements in the Eastern Region. Since 1998, production from the domestic wellfields has decreased by over $60 \%$ [5].

The objective of this study is to analyze the groundwater chemistry of the aquifer systems within the study area in terms of the prevailing natural (climatic, geological and hydrgeological) and man-induced (mainly agricultural) conditions and to evaluate the suitability of groundwater for different purposes.

\section{Geological and Hydrogeological Settings}

The study area is located South-Easterly from Al-Ain in 
the most eastern part of the Emirate of Abu Dhabi. It comprises Neima area to the north, Mubazarah to the east and Ain Bu Sukhanah to the west (Figure 1).

Jabal Hafit, the main mountain in the study area, is composed nearly of limestones and dolomites [6,7]. The gravel plain consists of a gently inclined gravel and sand plain, built up of the down-wash material drained by wadis from the eastern mountains. The continuation of the wadi courses to the north is marked by a string of patches of sabkhas, formed at the times of flood due to the rise of groundwater level [8]. The western part of the investigation area is dominated by dune fields and most of the study area is covered by Quaternary deposits. Four types of Quaternary deposits have been recognized in the study area and these are fluvial Deposits, desert plain deposits, sabkha deposits and aeolin sands $[9,10]$.

The geology of Jabal Hafit has significant impact on the hydrogeology of the area. The water bearing formations of the study area are mainly composed of alluvial deposits in the upper most part that underlained by clay, gypsum, limestone and marl lithofacies (Figure 2). The depth to water level varies according to the ground elevation and aquifer type. Fifteen large diameter wells have been drilled in the wellfield of the Mubazarah area with depths ranging from 90 to 200 meters and yields of 4600 $\mathrm{m}^{3} / \mathrm{d}$ which mainly are ascribed to fracture permeability and dissolution. The measured discharge of the wells to the pond west of the wellfield was $21,000 \mathrm{~m}^{3} / \mathrm{d}$. Wells that produce water with relatively high temperature and specific conductance are located close to the fold axis of the Jabal Hafit as compared to wells that produce cooler and fresher water which are located further from the axis. Deep fractures may act as conduits to bring thermal and saline water close to the surface before it cools or becomes diluted. The source of the water may be either meteoric water that rises by hydraulic pressure after having descended to a great depth or saline water that ascends due to gas pressure or thermal gradient. The flux of recharge water through Jabal Hafit may be greater than the lateral or upward flow of saline water into the conduits. Therefore, the result is water in the mixing zone that is brackish. The water in the conduits is heated by normal geothermal gradient at a depth of approximately 2000 meters below the surrounding land (3000 meters below the Jabal). The conduits bring the mixed water to the base of the clastic aquifer where it enters the shallow regional flow system. The aquifer water cools to near the ambient aquifer temperature, and becomes even more dilute. Water levels in the area ranges from 5.71 to $60.94 \mathrm{~m}$ below land surface and the level of water table is declining in those wells that are frequently pumped or are adjacent to pumped wells [11].

An old municipal well in Neima area began to flow in early February 2003 after reportedly being abandoned

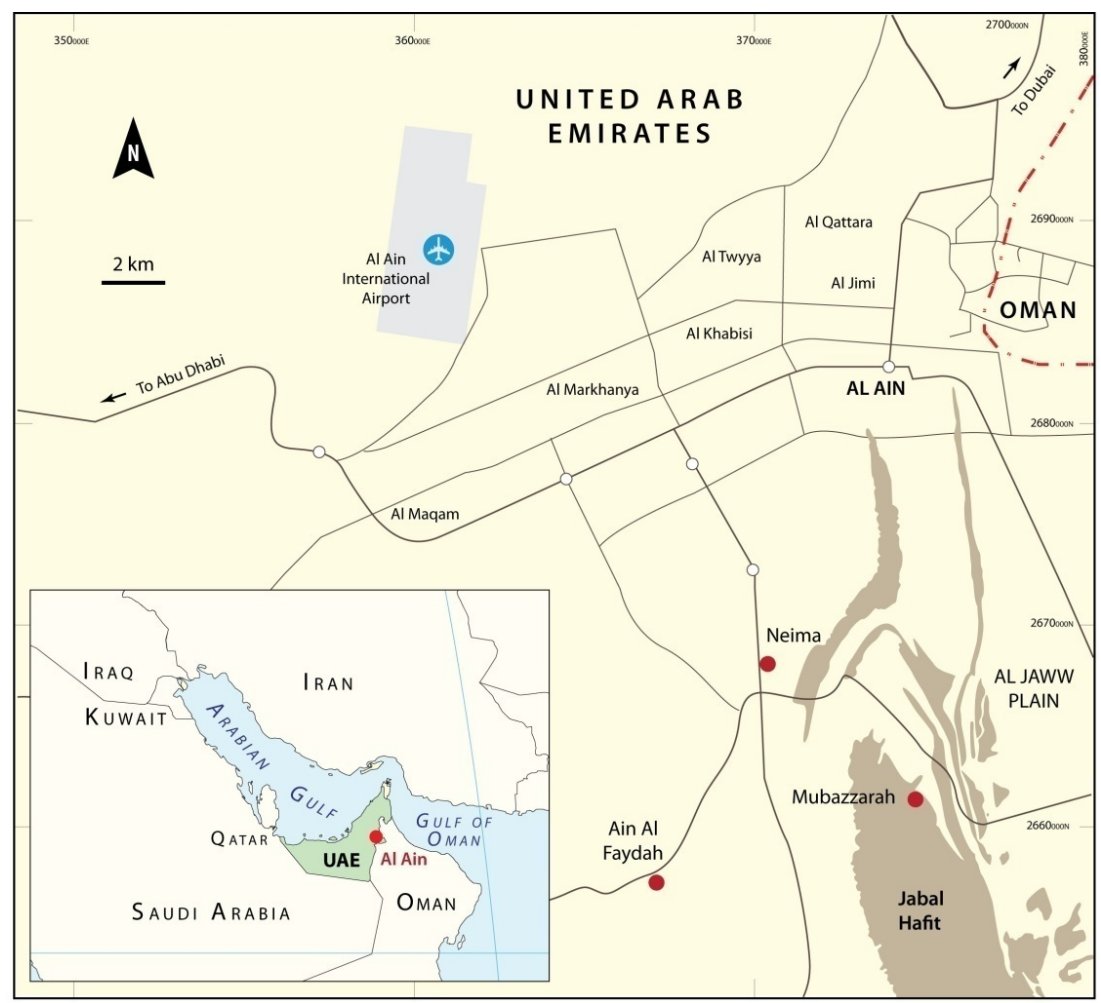

Figure 1. Map showing the location of the study area. Inset map showing the location of the UAE and study area relative to the Arabian Peninsula. 


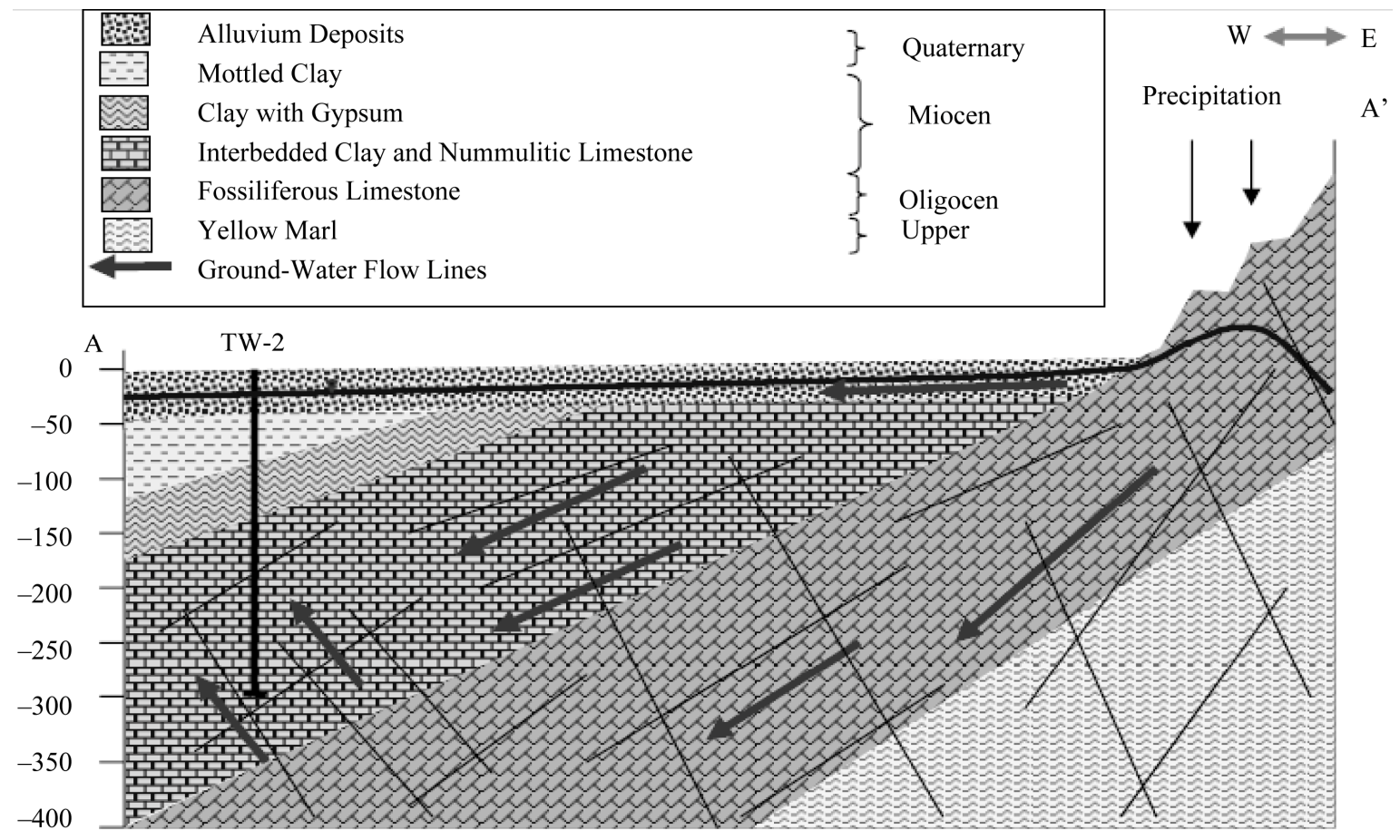

Figure 2. Conceptual geohydrologic cross-section of the study area (after [12]).

about 10 years ago because it had dried up. The well is located about 6 kilometers south of Al-Ain city, and is about 2 kilometers north of the road at the base of Jabal Hafit. The well was supposedly drilled some 15 years ago to a depth of $550 \mathrm{ft}$ [12]. Fresh and brackish water of limited areal extent is found within limestones in the Jabal Hafit area. In the vicinity of the rock outcrop, the limestone aquifer is unconfined and further (down dip) away from the rock outcrop, the limestone aquifer is either semi-confined or confined by underlying and overlying rock units [11].

Ain Bu Sukhanah or sometimes called Ain Al-Faydah is located less than $2 \mathrm{~km}$ to the west of Jabal Hafit. It apparently discharges from a gypsum aquifer, probably well karstified adjacent to the western side of Jabal Hafit. The discharge of Ain $\mathrm{Bu}$ Sukhanah spring reflects no direct relation with groundwater levels in the study area when groundwater level data of 1990 and 1991 are compared. The groundwater level at the nearby observation well declined from 34.1 in 1990 to $42.2 \mathrm{~m}$ in 1991 below ground surface. Whereas the spring discharge increased from $1.58 \times 10^{6} \mathrm{~m}^{3} / \mathrm{yr}$ in 1990 to $2.5 \times 10^{6} \mathrm{~m}^{3} / \mathrm{yr}$ in 1991 [13]. If it is assumed that $60 \mathrm{~mm}$ (out of $100 \mathrm{~mm}$ ) infiltrates then some 2.5 million $\mathrm{m}^{3}$ is estimated as entering the limestone mass. This quantity corresponds quite closely to the annual yield of the spring suggesting that the Jabal Hafit is the feeding area for the spring [14]. A possible explanation for the brackish water at Bu Sukhanah spring is that fresh water of the Jebel Hafit becomes brackish on its way through the gypsum.

\section{Methodology}

For this study, 53 water samples were collected from governmental and private wells (Figure 3 ). In addition, 3 surface water samples were collected from different surface water localities in the study area.

The temperature, Electrical Conductivity (EC) $(\mu \mathrm{S} / \mathrm{cm})$ and Total Dissolved Solid (TDS) contents in $\mathrm{mg} / \mathrm{l}$ were measured directly in the field. The collected groundwater samples were then analyzed for major cations $\left(\mathrm{K}^{+}, \mathrm{Na}^{+}\right.$, $\mathrm{Mg}^{+}$and $\left.\mathrm{Ca}^{2+}\right)$ and major anions $\left(\mathrm{HCO}_{3}^{2-}, \mathrm{SO}_{4}^{2-}, \mathrm{Cl}^{-}\right)$in the Central Laboratories Unit (CLU) at UAE University. All chemical data and their processes and acquisitions are listed in the Appendix.

\section{Results and Discussions}

The main measured physical properties of the groundwater in the study area including, electrical conductivity (EC), total dissolved solids (TDS), temperature and chemical properties of the major ions are presented.

\subsection{Physical Properties}

The electrical conductivity of groundwater samples collected from the study area varied between $2.989 \mathrm{mS} / \mathrm{cm}$ in a farm west of Neima (Well No. 9) and $27.188 \mathrm{mS} / \mathrm{cm}$ in Ain Bu Sukhanah (Well No. 34) (Figure 4). The data shows that in the north (Neima Area), the EC values are less than $10 \mathrm{mS} / \mathrm{cm}$, while in Mubazzarah area, the EC values between 15 and $25 \mathrm{mS} / \mathrm{cm}$, and to the west of 


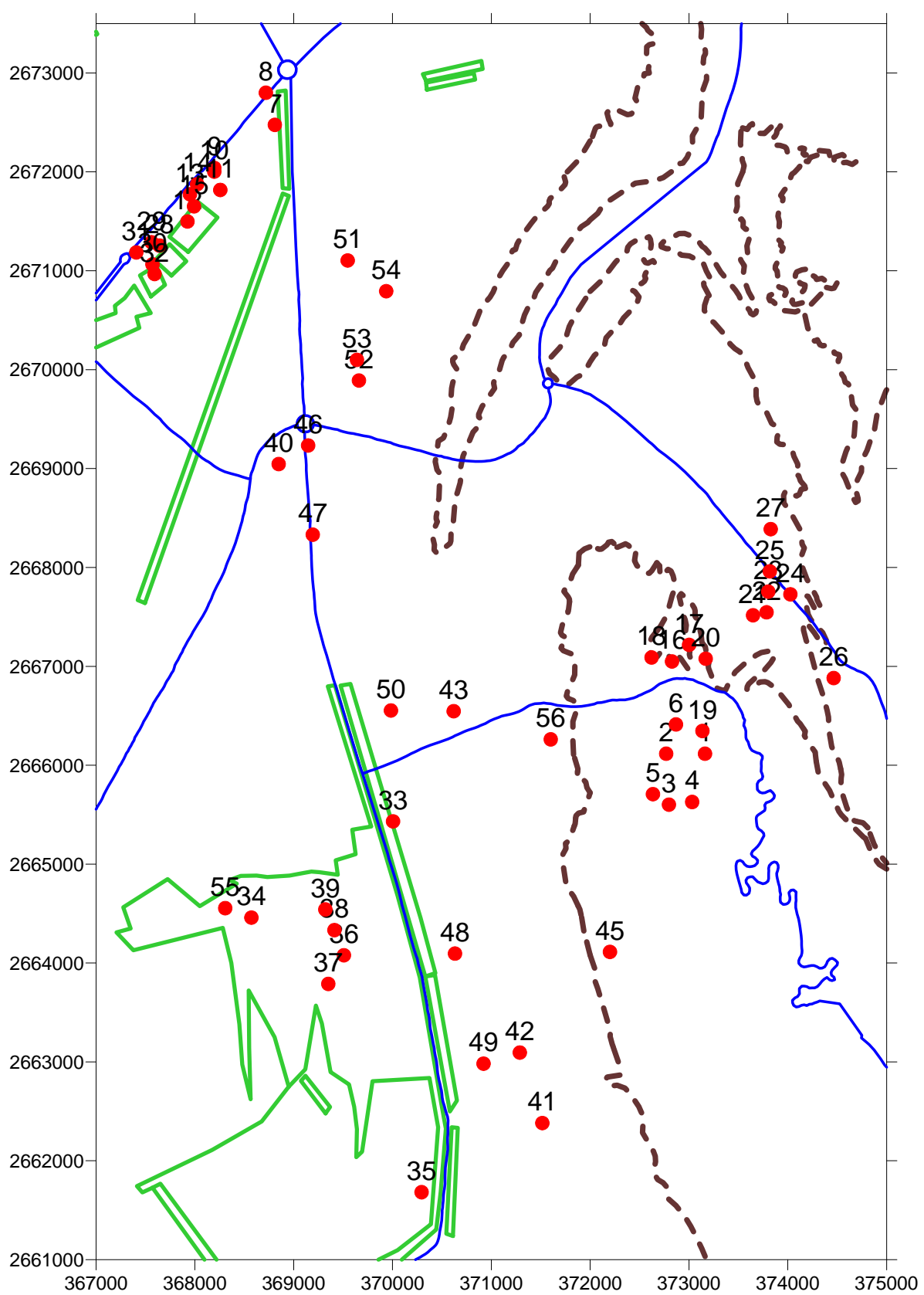

Figure 3. Map showing the location of groundwater samples in the study area.

Jabal Hafit at Ain Bu Sukhanah, the EC values exceed 30 $\mathrm{mS} / \mathrm{cm}$.

These high EC values might result from using the groundwater in these areas in agricultural activities. In the study area, the total salinity of groundwater ranges between 1910 and 17,400 mg/l, with a mean value of $6714 \mathrm{mg} / \mathrm{l}$ (Figure 5). The salinity increases from east to west in the direction of groundwater flow. The higher salinity content is recorded for the central and western regions (Mubazarah and Ain-Bu Sukhanah areas), whereas at Neima area in the north, it is quite low and increases towards the south. Groundwater samples of the study area are classified as brackish except Wells No. 34, 36 and 38 which are of saline water based on USGS/ NDC classification [3]. Using ground-water for irrigation purposes is the main reason for high TDS values as well as the lithological constitutes of the water-bearing formation. The temperature of the collected groundwater samples in the study area varies between $29^{\circ} \mathrm{C}$ and $49.1^{\circ} \mathrm{C}$ with a mean value of $35.59^{\circ} \mathrm{C}$. The temperature increases from west to east, opposite to the direction of groundwater flow. Where as, Mubazarah is characterized by the highest water temperature because of thermal origin of groundwater in that area. 


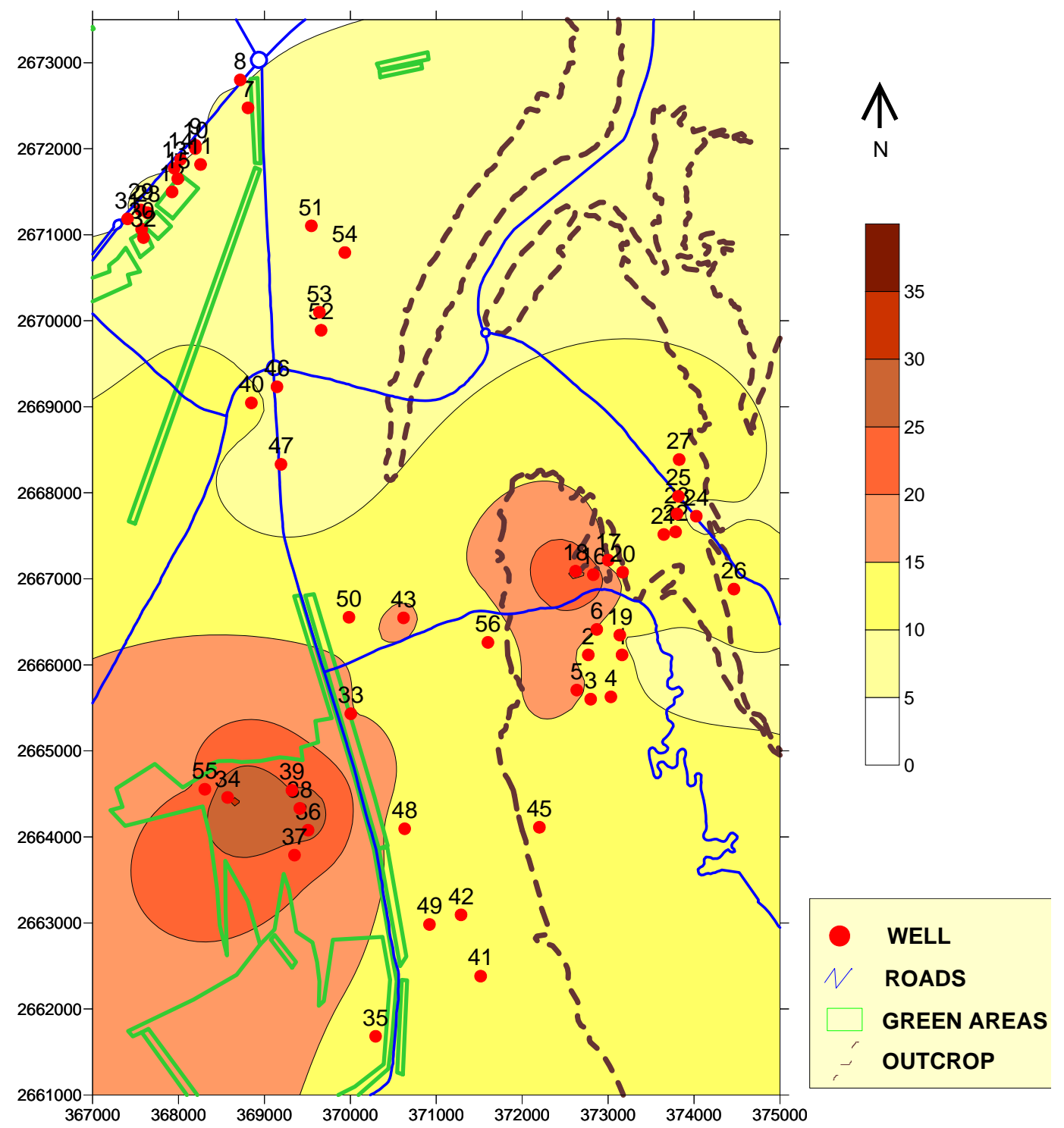

Figure 4. Iso-Electrical Conductivity $(\mu \mathrm{S} / \mathrm{cm})$ contour map of groundwater samples collected from the study area.

\subsection{Chemical Properties}

The major cations in water are potassium $\left(\mathrm{K}^{+}\right)$, sodium $\left(\mathrm{Na}^{+}\right)$, magnesium $\left(\mathrm{Mg}^{+2}\right)$, calcium $\left(\mathrm{Ca}^{2+}\right)$ and the major anions are chloride $\left(\mathrm{Cl}^{-}\right)$, sulphate $\left(\mathrm{SO}_{4}^{2-}\right)$ and bicarbonate $\left(\mathrm{HCO}_{3}^{2-}\right)$. It is noticed that the cation charge balance is too high and exceeded the $5 \%$. This abnormal of charge balance mainly attributed to high groundwater salinity as it is indicated by Murad (2004) in eastern part of the UAE. Each of these constituents and their relationship to each other are discussed below and presented in the Appendix.

\subsubsection{Major Cations}

The majority of the groundwater samples of the study area has the cationic order of: $\mathrm{Na}^{+}>\mathrm{Ca}^{2+}>\mathrm{Mg}^{2+}>\mathrm{K}^{+}$. Sodium ion concentrations in groundwater of the study area ranged from $386.5 \mathrm{mg} / \mathrm{l}$ at northwest of Mubazarah in Neima area (Well No. 31) to $4953.5 \mathrm{mg} / \mathrm{l}$ at Ain Bu Sukhanah (Well No. 38). It is clear that the concentration of sodium is low at Neima and the northern part of the study area and it is high in While Mubazarah and Ain Bu Sukhanah. The positive relationship between sodium and chloride $\left(\mathrm{r}^{2}=0.81\right)$ (Figure 6) is a strong evidence for extensively using of brackish groundwater for irrigation.

The most common form of calcium in sedimentary rocks is carbonates, particularly as limestone or dolomite, which are dominant in the study area. The calcium ion concentration in groundwater of the study area ranged from $110.7 \mathrm{mg} / \mathrm{l}$ at Neima (Well No. 47) to $1813 \mathrm{mg} / \mathrm{l}$ at Ain Bu Sukhanah (Well No. 34 west of Jabal Hafit). The calcium concentrations of groundwater samples showed 


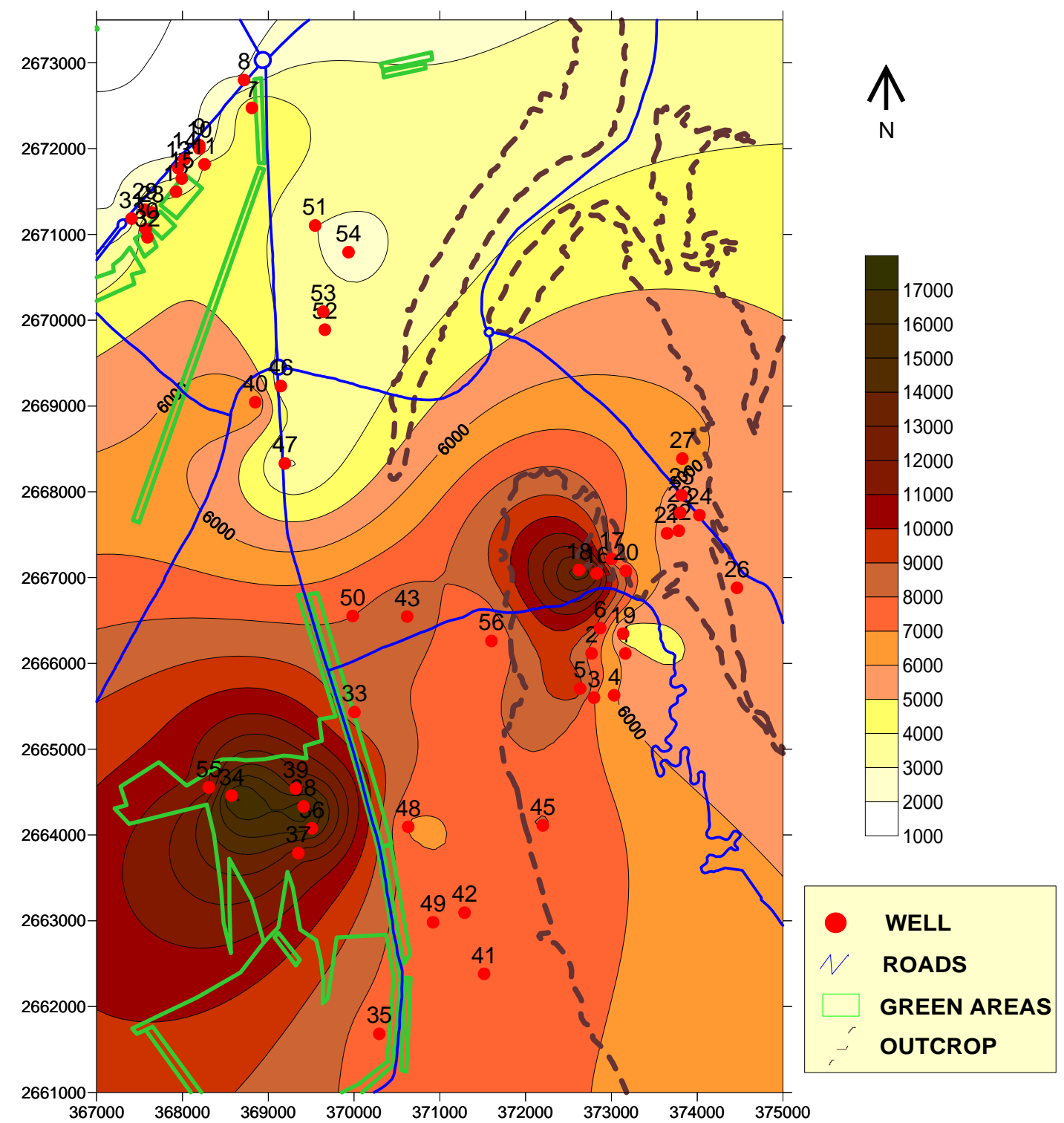

Figure 5. Iso-salinity (mg/l) contour map of groundwater in the study area.

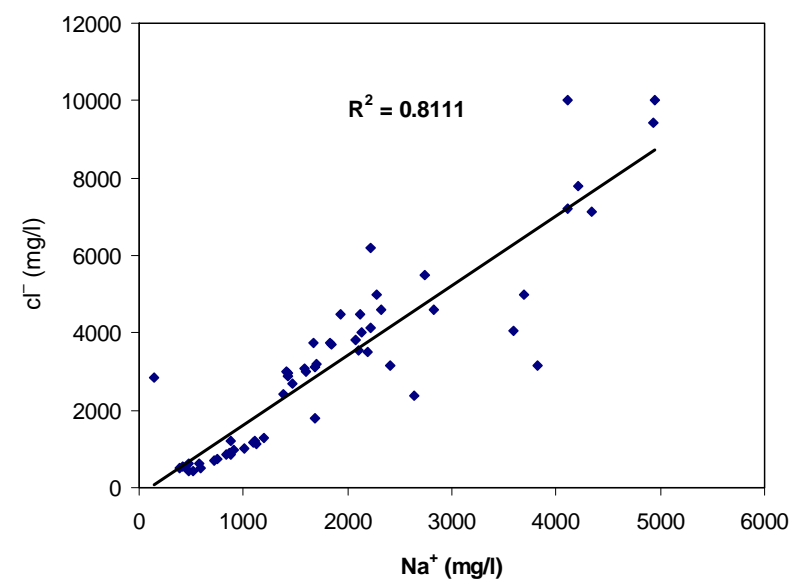

Figure 6. The relationship between sodium and chloride concentrations for the groundwater in the study area. a gradual increase from east to west in the direction of groundwater flow. High calcium ion concentrations encountered in Ain Bu Sukhanah. The calcium abundance might result from the limestone dissolution of Jabal Hafit [15].

The magnesium ion $\left(\mathrm{Mg}^{2+}\right)$ concentrations in fresh water are generally less than that of calcium because of low geochemical abundance of magnesium [16]. The concentration of $\mathrm{Mg}^{2+}$ in collected groundwater samples in the study area ranged from 120 to $5173 \mathrm{mg} / \mathrm{l}$. The maximum $\mathrm{Mg}^{2+}$ concentrations exist in the western side of Jabal Hafit (Ain Bu Sukhanah). The presence of dolomite in Jabal Hafit could be elevated the magnesium concentration at Ain $\mathrm{Bu}$ Sukhanah as the dolomite is the main source of magnesium in groundwater [17].

The natural sources of potassium in water are the ig- 
neous rocks as feldspars (orthoclase and microcline), some mica and sedimentary rocks as silicate and clay minerals [17]. The potassium content ranges between 25.7 $\mathrm{mg} / \mathrm{l}$ at Neima (Well No. 10) and $1656.8 \mathrm{mg} / \mathrm{l}$ at Ain Bu Sukhanah (Well No. 38). In general, potassium ion concentrations are low at Neima and Mubazarah areas, while high $\mathrm{K}^{+}$concentrations are recognized in the west of Jabal Hafit at Ain Bu Sukhanah. This high potassium concentration can be attributed to the presence of clay layer, overlained the gypsum aquifer of Ain Bu Sukhanah.

\subsubsection{Major Anions}

The sequence of the major anions in the majority of groundwater of the study area has the order of: $\mathrm{Cl}^{-}>$ $\mathrm{SO}_{4}^{2-}>\mathrm{HCO}_{3}^{2-}$. The chloride ion concentrations in the study area range between $430 \mathrm{mg} / \mathrm{l}$ at Neima (Well No. 9) and 10,000 mg/l in Ain Bu Sukhanah (Well No. 38). Low values of chloride concentration are encountered at the farms west to Neima, while high values are observed at Mubazarah and Ain Bu Sukhanah. One possible explanation for the high concentration of chloride in Mubazarah and Neima is the entrapped saline water within the limestone sequence of Jabal Hafit, or it can be the agricultural activities from the positive relationship between $\mathrm{Cl}^{-}$and $\mathrm{Br}^{-}$(Figure 7).

Sulphate ions $\left(\mathrm{SO}_{4}^{2-}\right)$ are derived from gypsum $\left(\mathrm{CaSO}_{4} \cdot 2 \mathrm{H}_{2} \mathrm{O}\right)$ or anhydrite $\left(\mathrm{CaSO}_{4}\right)$ in sedimentary rocks [15]. These two minerals are present in the study area as thick beds or streaks in the limestone strata and are sufficiently soluble to cause water in contact with them to be high in sulphate [18]. The value of sulphate concentrations in the study area ranged between $495 \mathrm{mg} / \mathrm{l}$ at Mubazarah (Well No. 1) and $6280 \mathrm{mg} / \mathrm{l}$ in the south Ain Bu Sukhanah (Well No. 35). Sulphate ion concentrations are low at Mubazarah; while Neima and Ain Bu Sukhanah are characterized by high concentrations which might be related to the presence of gypsum and anhydrite within

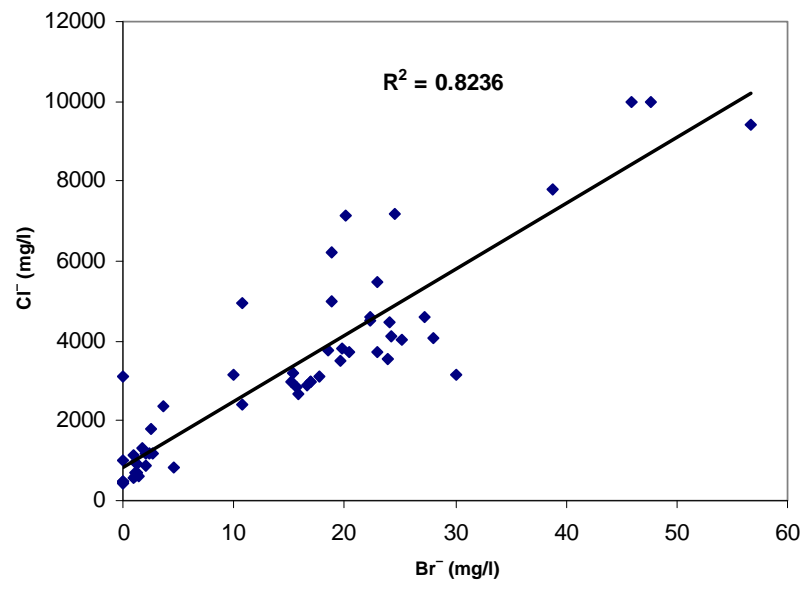

Figure 7. The relationship between chloride and bromine for the groundwater in the study area. the limestone sequence of Jabal Hafit.

Most bicarbonate ions $\left(\mathrm{HCO}_{3}^{2-}\right)$ in groundwater are derived from carbon dioxide in the atmosphere and soils, and by dissolution of carbonate rocks [17]. Bicarbonate concentrations in groundwater of the study area ranged from $65.07 \mathrm{mg} / \mathrm{l}$ south Mubazarah (Well No. 45) to 520.5 $\mathrm{mg} / \mathrm{l}$ south Neima (Well No. 47). The concentration of bicarbonate shows a steady increase in the north-west direction, where Neima is characterized by high bicarbonate concentrations. Dissolution of Jabal Hafit carbonate considered the main source for releasing bicarbonate to the groundwater in the study area.

\subsubsection{Hydrochemical Water Types}

The water type is represented by each anion and cation that exceeds 15 equivalent percentages, arranged from the lowest to the highest cationic and anionic concentrations [19]. Four anionic groups with their 14 equivalent cationic combinations are distinguished and give rise to the different water types (Appendix). The anionic and cationic compositions of groundwater indicate that the chloride and sodium ions often acquire the highest concentrations. While that, the sulphate with magnesium and calcium ions compositions reveal the second order in their concentrations. The intermediate concentration of bicarbonate and sulphate may be characterized the mixing of such water by the recent fresh water through the existing structural lineaments within the study area. This hypothesis is mainly supported by piper diagram (Figure 8) as most of the samples lie on the portions of dominancy of sulpahte and chloride which suggests seawater of relatively low freshening.

The predominance of sulphate anion concentration within Cl-sulphate group reflects the depth and distance from the catchment area as well as the leaching processes of the evaporitic rock constituents that enrich with cal cium,

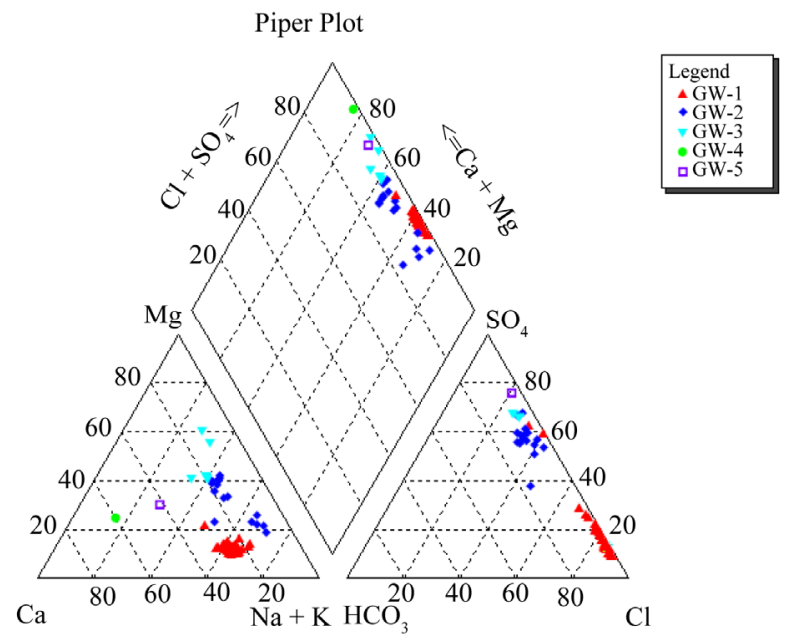

Figure 8. Piper diagram for groundwater samples from the study area. 
magnesium and sulphate ions. A water type zonation map is constructed to show the spatial variation of different water types within the study area (Figure 9).

\subsubsection{Hydrochemical Parameters}

About fifty percent of the analyzed groundwater samples indicate that the ratio of $\mathrm{Na}^{+} / \mathrm{Cl}^{-}$in meq/l is generally

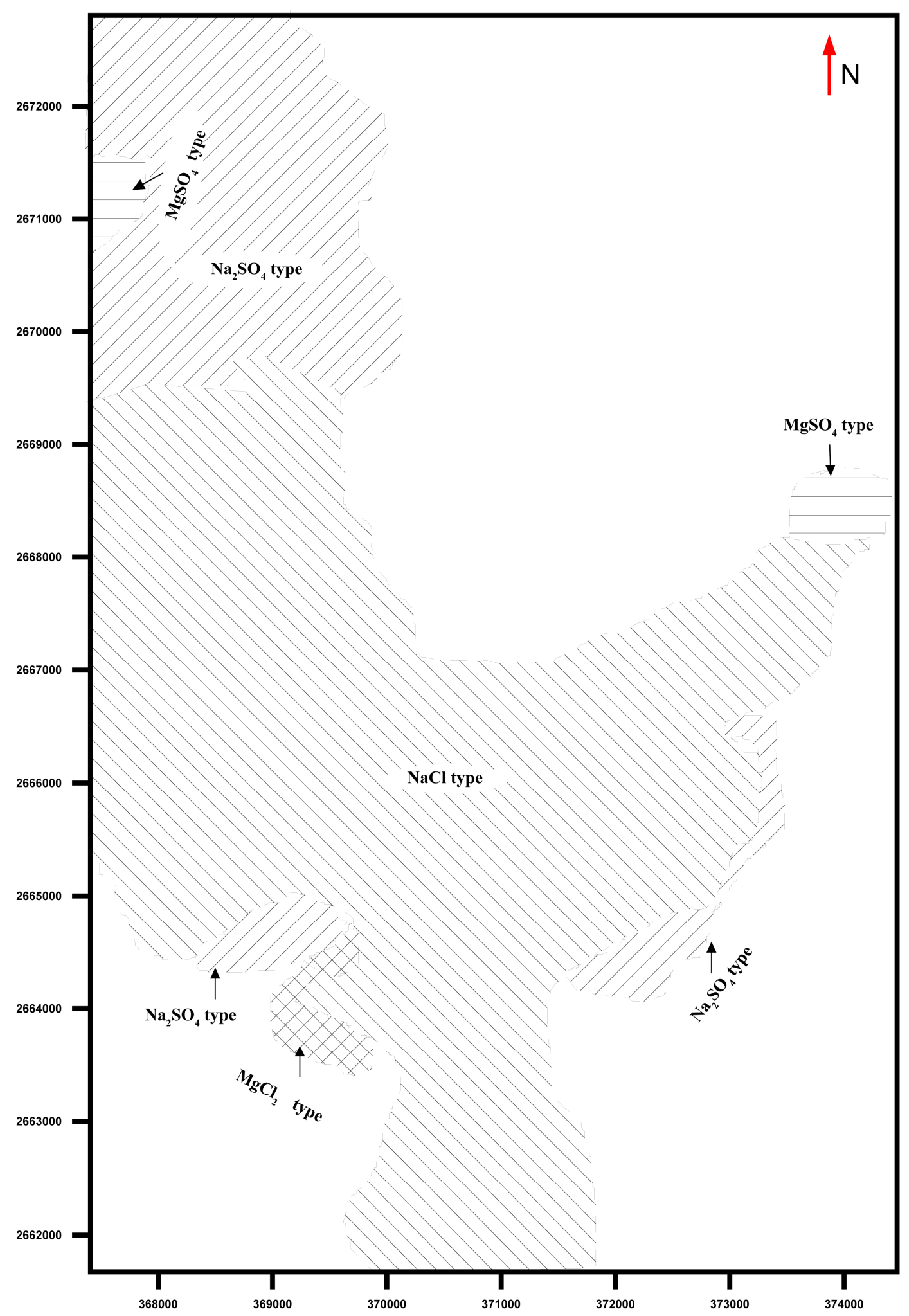

Figure 9. Water type zonation map for the study area. 
less than unity indicating the marine water origin, while that the others reveal values more than unity to reflect meteoric water genesis. The hydrochemical parameters in meq $/ 1$ of $\mathrm{K}^{+} / \mathrm{Cl}^{-}, \mathrm{Na}^{+} / \mathrm{Cl}^{-}, \mathrm{Ca}^{2+} / \mathrm{Cl}^{-}, \mathrm{Mg}^{2+} / \mathrm{Cl}^{-}$and $\mathrm{SO}_{4}^{2-} / \mathrm{CI}^{-}$are compared with the values of the standard seawater compositions [20] which are 0.0181, 0.8537, $0.0385,0.1986$, and 0.103 respectively. The calculated hydrochemical parameters relative to the seawater standard indicted a relative increase in the concentration of calcium, magnesium and sulphate ions.

This is highly reflecting the influence of the existing water bearing formations such as carbonate and evaporite sediments. In addition, a relatively high temperature of the existing groundwater assists the solubility of such ions through the water-rock interaction. The adsorbed sodium ions to the shaly sediments are effectively subjected to leaching by invading the meteoric water [21].

\subsubsection{Water Genesis and Hypothetical Salt Combinations}

The interpretation of chemical analyses of collected groundwater samples showed that the $\mathrm{Na}_{2} \mathrm{SO}_{4}$ is originated from deep percolation and $\mathrm{NaHCO}_{3}$ is from surface and shallow meteoric water conditions whereas $(\mathrm{K}+\mathrm{Na})-$ $\left(\mathrm{Cl} / \mathrm{SO}_{4}\right)<1$ and $\left.(\mathrm{K}+\mathrm{Na})-\left(\mathrm{Cl} / \mathrm{SO}_{4}\right)>1\right)$. In addition, the interpretation reflects the meteoric water genesis, where the ionic concentrations of the potassium and sodium ions are greater than chloride ions in solution. Wells No. 7 - 15, 28 - 32, 35, 37, 38, 40, 46, 47, 50, 51 54 represent the distribution of such water genesis within the area of investigation.

In spite of the meteoric origin of the water samples, salts of temporary hardness in the solution are not dominant and represented only by $\mathrm{Ca}\left(\mathrm{HCO}_{3}\right)_{2}$ except sample no. 47. On the other hand, salts of permanent hardness are of obvious existence within most of the samples and represented by $\mathrm{MgSO}_{4}$ and $\mathrm{CaSO}_{4}$. The appearance of such salts may be affected by the leaching processes of lithological constituents that rich in calcium, magnesium and sulphate ions as well as lacking the recharging sources. The leaching processes of deep percolating water that occurs among these lithological constitutes which contain groundwater of relatively warm or hot (about $40^{\circ} \mathrm{C}$ ) makes enrichment of calcium, magnesium and sulphate ions especially under over pumping performance and the absence of proper water management. The $\mathrm{NaHCO}_{3}$ water genesis with the hypothetical salt of $\mathrm{KCl}$, $\mathrm{NaCl}, \mathrm{MgCl}_{2}, \mathrm{CaCl}_{2}, \mathrm{CaSO}_{4}$ and $\mathrm{Ca}\left(\mathrm{HCO}_{3}\right)_{2}$ is represented by well no. 55. The occurrence of $\mathrm{MgCl}_{2}$ and $\mathrm{CaCl}_{2}$ water types within the salt combinations might reflect the upward leakage of deep marine water origin in which the water reserves its meteoric genesis. On the contrary, the other groundwater samples indicate the ap- pearance of $\mathrm{MgCl}_{2}$ and $\mathrm{CaCl}_{2}$ water types which could reflect the marine water origin. However, the $\mathrm{Cl} /(\mathrm{Na}+\mathrm{K})$ $>1$ shows that the marine genesis of $\mathrm{MgCl}_{2}$ type.

The existing salt combinations of $\mathrm{MgCl}_{2}$ water genesis reflects the appearance of $\mathrm{Ca}\left(\mathrm{HCO}_{3}\right)_{2}$ as salt of temporary hardness that is may be due to the nearby of the $\mathrm{MgCl}_{2}$ zone to the $\mathrm{Na}_{2} \mathrm{SO}_{4}$ water origin zone (Figure 10) that is greatly affected by the water quality or by the shallow depth of the present groundwater. On the other hand, the $\mathrm{Ca}\left(\mathrm{HCO}_{3}\right)_{2}$ as temporary salt is of limited occurrence within the salt combinations of $\mathrm{CaCl}_{2}$ water origin. A complete disappearance of $\mathrm{Mg}\left(\mathrm{HCO}_{3}\right)_{2}$ as a temporary hardness salt could be attributed to the small equivalent percentage of $\mathrm{CaSO}_{4}$ that exists [22]. Both $\mathrm{CaCl}_{2}$ and $\mathrm{MgCl}_{2}$ water geneses show that the dominant salts of permanent hardness are $\mathrm{MgSO}_{4}$ and $\mathrm{CaSO}_{4}$ that might reflect the influence of leaching processes on the evaporite deposits that rich in calcium and magnesium sulfates within the lithologic constituents of the water bearing formations.

\subsubsection{Lateral Hydrogeochemical Variation}

In order to study the geographical changes in the chemical compositions of groundwater within the studied area, three different hydrochemical cross-sections were constructed. Along these sections, the existing structures represented by faulting and folding reveal their impact in the form of different water genesis within the aquifer. The cross section (A-A') that extends NW-SE (Figure 11) showed that the chemical change in water genesis reveals the occurrence of contiguous different water genesis starting at southeast by $\mathrm{CaCl}_{2}$ type existing in water wells $49 \& 33$. The neighbored aquifer toward the northwest indicates groundwater of terrestrial $\mathrm{Na}_{2} \mathrm{SO}_{4}$ genesis (Wells No. 47 \& 13). The existence of those distinct water types, where each one preserves its definite characteristics may declare the discontinuity between them through probable existing faults.

The aquifer with $\mathrm{CaCl}_{2}$ marine water genesis (Wells No. $49 \& 2$ ) along the profile (B-B'), which is extending SW-NE (Figure 12), is bounded from northeast by $\mathrm{MgCl}_{2}$ of marine water genesis (Wells No. 20 \& 27). The existence of both exchangeable $\mathrm{MgCl}_{2}$ and $\mathrm{CaCl}_{2}$ marine water genesis give evidence about the effect of both geologic structures particularly the faulting and the high variable lithofacies of water-bearing formations in the prevailing of such exchangeable water origin through the same aquifer.

The third hydrochemical cross-section (C-C') that extended SE-NW (Figure 13) passes through water Wells No. $27,54 \& 13$ trending in SE-NW direction. These wells lie within aquifer zone indicating $\mathrm{MgCl}_{2}$ and $\mathrm{Na}_{2} \mathrm{SO}_{4}$ water genesis. This variation in groundwater origin may 


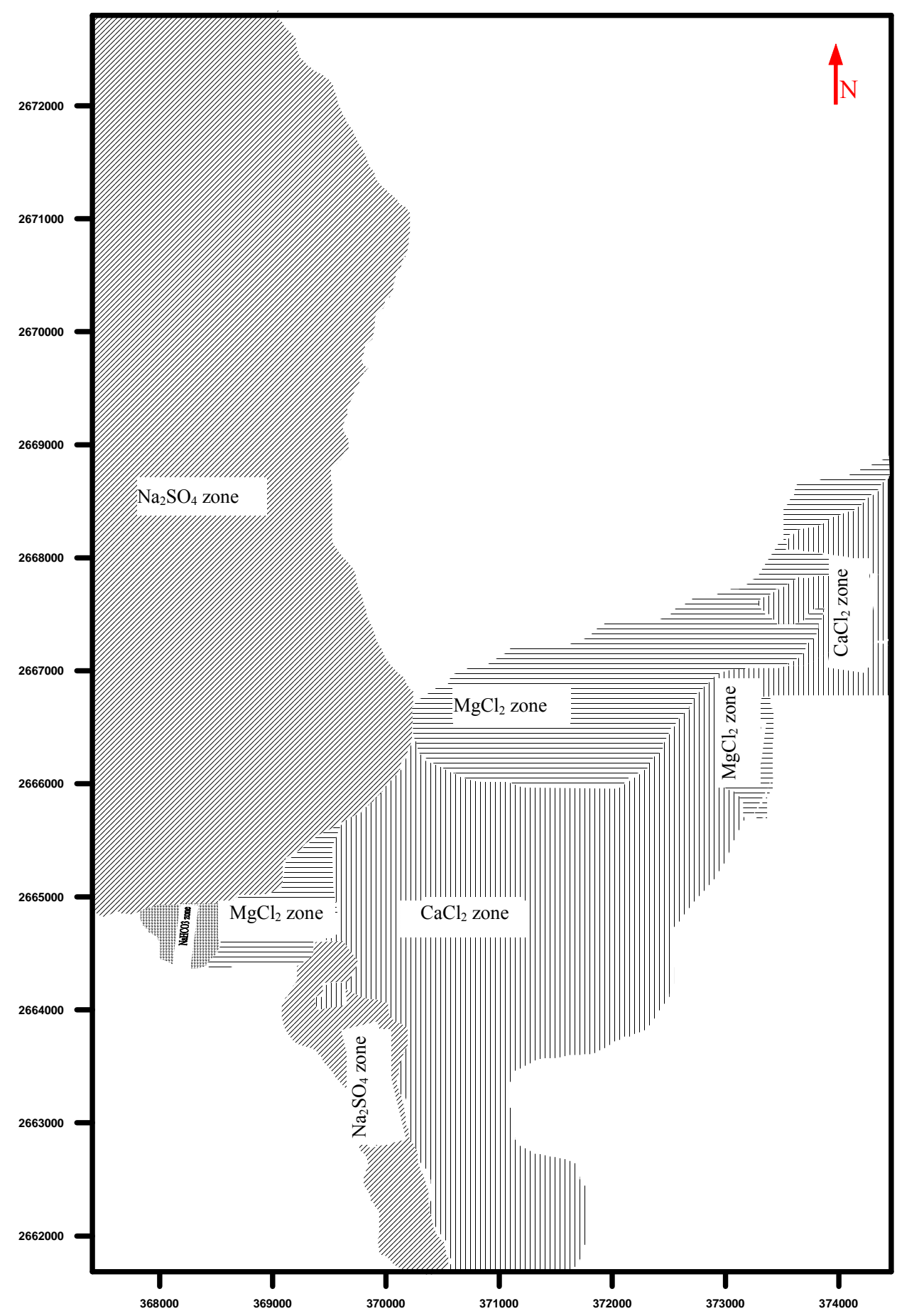

Figure 10. Water genesis zonation map for the study area.

greatly reflect the depth that apart from the main recharge source and the nature of the excessive pumping from the groundwater wells that lies close to Jabal Hafit zone. However, $\mathrm{Na}_{2} \mathrm{SO}_{4}$ water genesis indicates shallow depths and the groundwater connection with the atmosphere while that the $\mathrm{MgCl}_{2}$ reveals the impact of over pumping within the wells neighboring to Jabel Hafit zone as well as the leaching process of the leachable forma- tions such as clay and evaporite rocks that form the major constitutes of the aquifer.

\subsubsection{Groundwater Utilities}

The suitability of groundwater in the study area for domestic and agricultural purposes is evaluated. Usually, water applied for domestic purposes has certain standard specification as regards to its physical, chemical and 


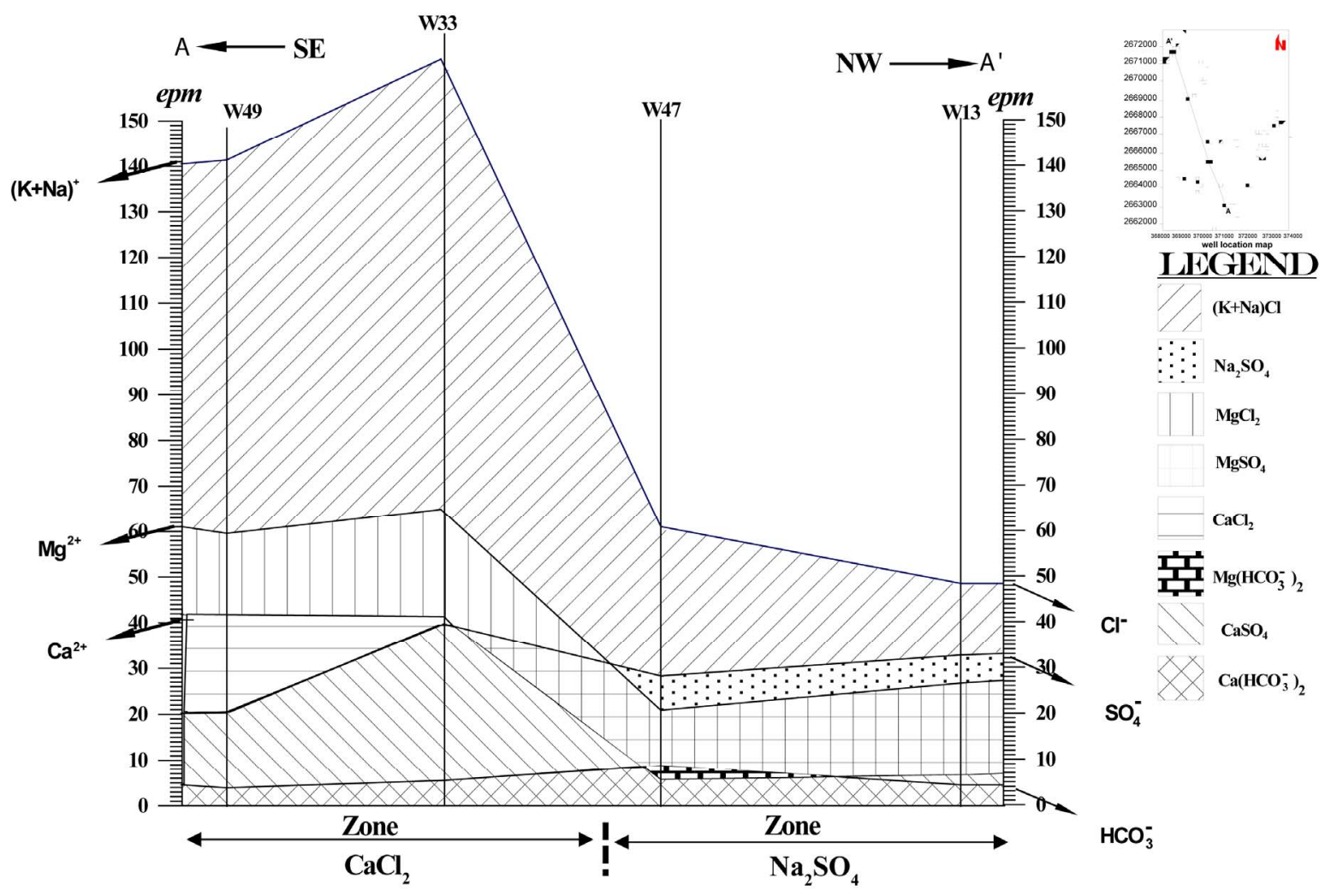

Figure 11. Hydrochemical cross section (A-A'). The inset map showing the location of the cross section.

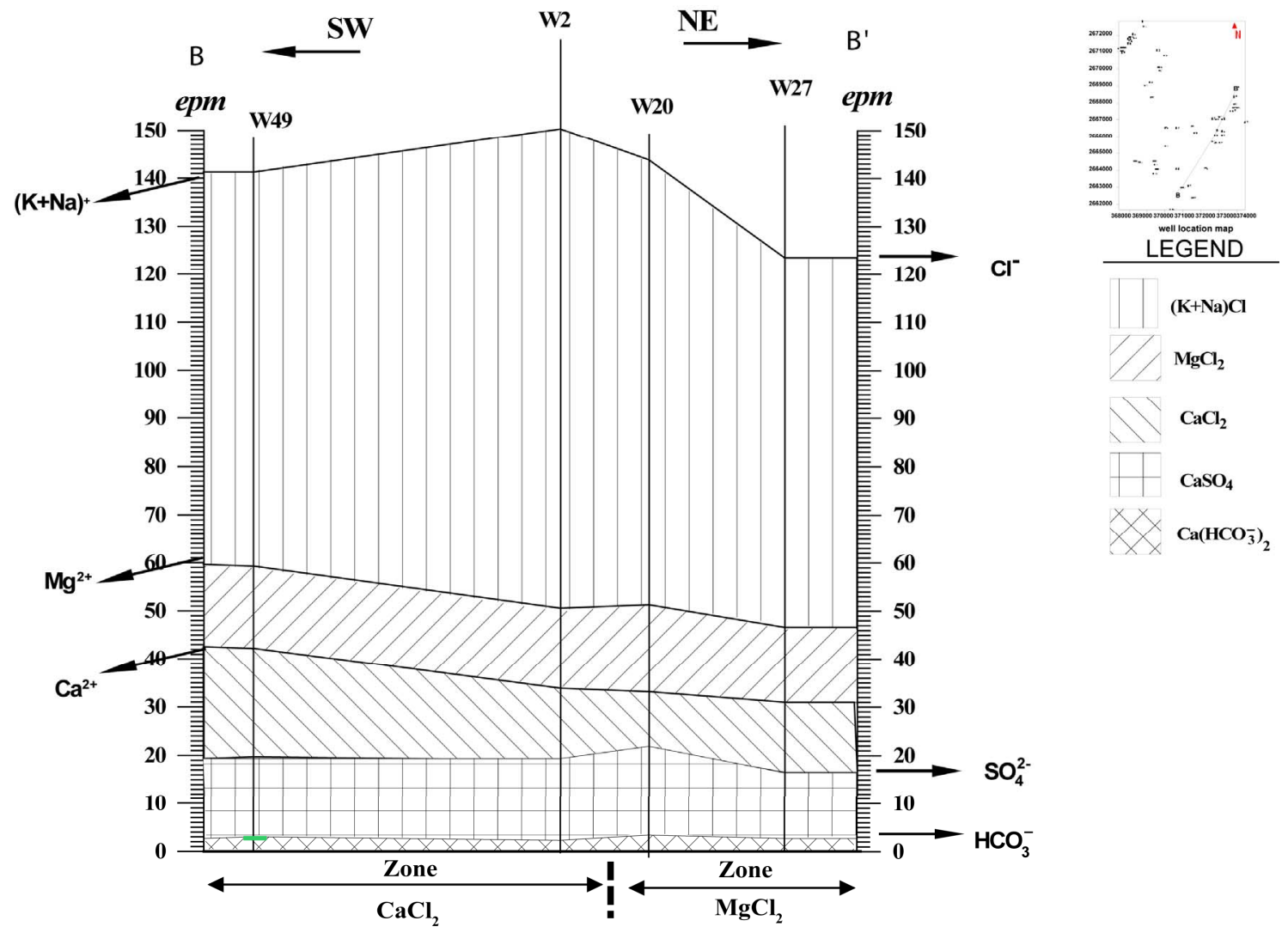

Figure 12. Hydrochemical cross section (B-B'). Inset map showing the location of the cross section. 


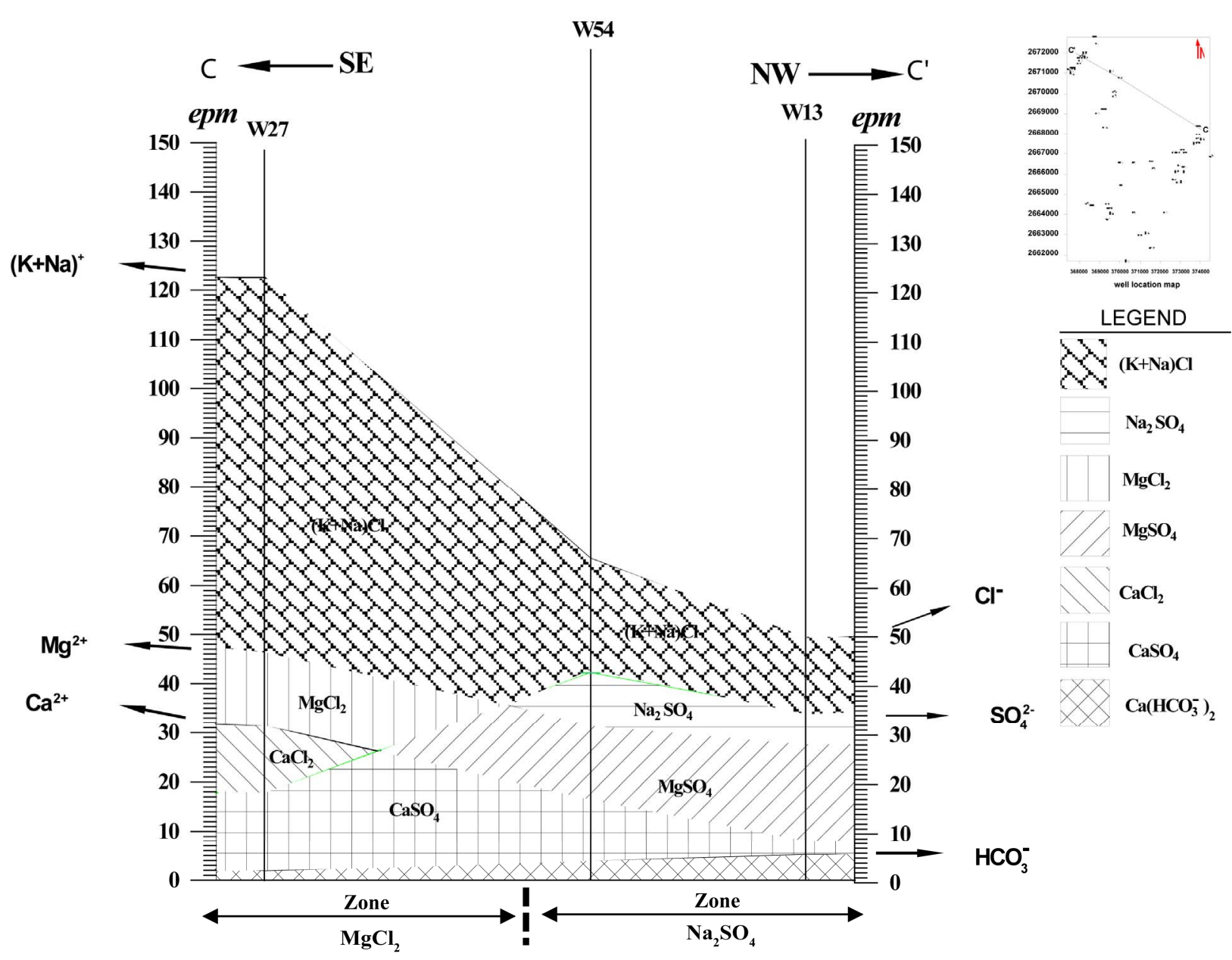

Figure 13. Hydrochemical cross section (C-C'). Inset map showing the location of the cross section.

biological properties. These standards are intended primarily to protect human health. However, the groundwater in the study area is not suitable for drinking purposes due to the high TDS values. The suitability of groundwater in the study area for agriculture practices is assessed using Sodium Adsorption Ratio (SAR) values [23]. The SAR ranged between 1.3 in north-east Mubazarah (Well No. 25) and 28.18 at Mubazarah (Well No. 18) (Figure 14). Groundwater in Neima is characterized by limited harmful effect on plants in the north to a moderate harmful effect for plants in the south. In Ain Bu Sukhanah, groundwater can cause moderate to high harmful effects for plants. Finally, Mubazarah is characterized by groundwater with high to very high damaging risk if it used for irrigation.

\section{Conclusions}

The total dissolved content of the groundwater shows a general increasing trend from east to west of the northern Jabal Hafit in Al-Ain area in the eastern part of Abu Dhabi Emirate, UAE. An area of high TDS content is encountered in Ain Bu Sukhanah west from Jabal Hafit.
This increase of TDS is attributed to the brine moving upward near Ain Bu Sukhanah and the existence of sabkhas in areas of low elevation west of Jabal Hafit. The sequence of major cations and anions dominance in groundwater in the study area have the order of: $\mathrm{Na}^{+}>\mathrm{Ca}^{2+}>$ $\mathrm{Mg}^{2+}>\mathrm{K}^{+}$and $\mathrm{Cl}^{-}>\mathrm{SO}_{4}^{2-}>\mathrm{HCO}_{3}^{2-}$ respectively. According to the measured EC and calculated SAR values, groundwater in Neima is characterized by limited harmful effect on plants in the north to a moderate harmful effect for plants in the south. The groundwater of Ain Bu Sukhanah can cause moderate to high harmful effects for plants. Mubazarah is characterized by groundwater with high to very high damaging risk if it used for irrigation.

Brackish groundwater was used for agriculture activities in the region as it is clear from a positive relationship between chloride and sodium concentrations. In addition, high concentrations of chloride in groundwater in Mubazarah and Neima areas might be related to the entrapped saline water within the limestone sequence of Jabal Hafit, or it can be the agricultural activities from the positive relationship between $\mathrm{Cl}$ and $\mathrm{Br}$. High sulphate concentra- 


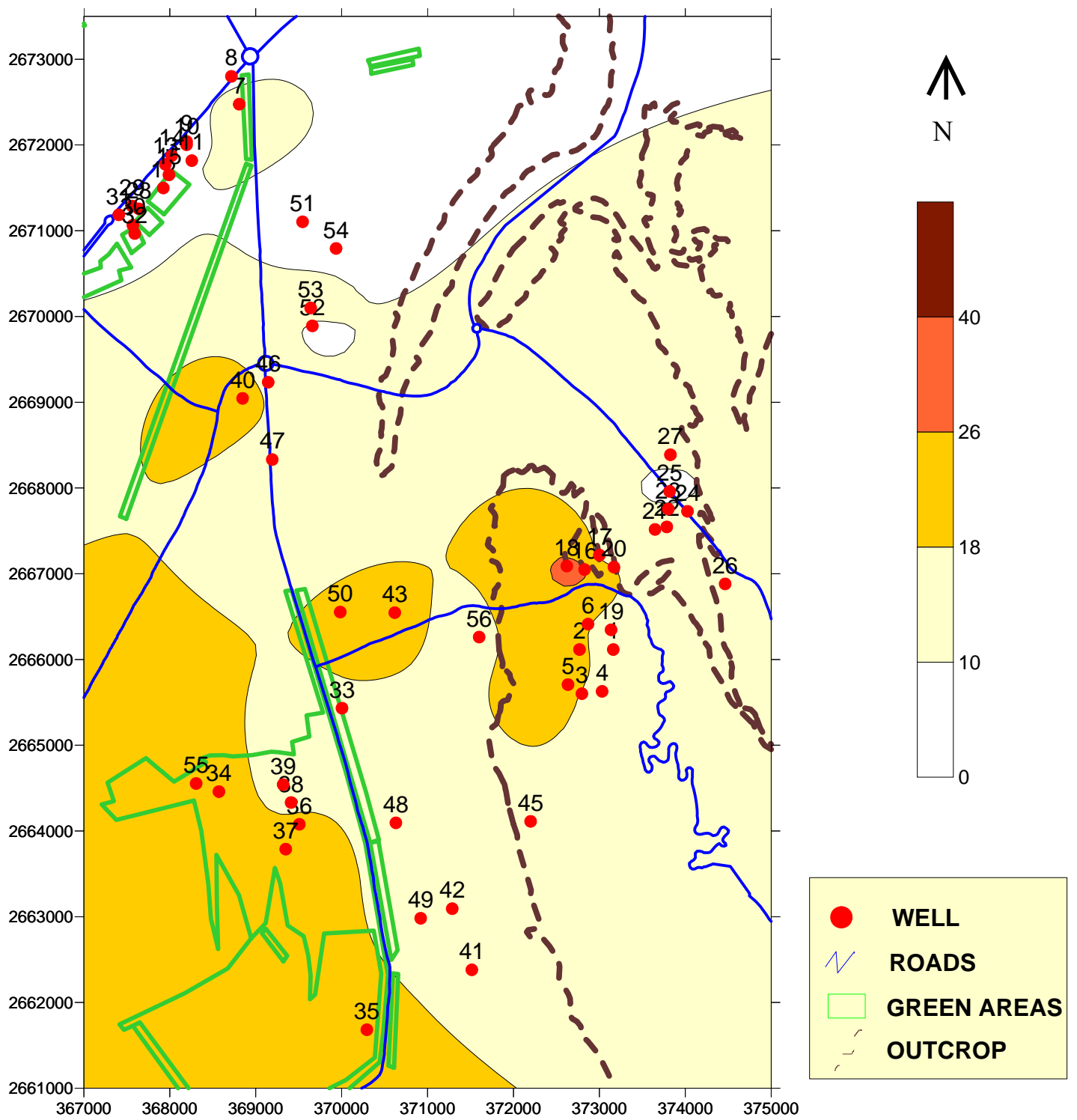

Figure 14. Distribution map of the SAR in the study area.

tions in groundwater might be related to the presence of gypsum and anhydrite within the limestone sequence of Jabal Hafit. The presence of bicarbonate and sulphate may indicate mixing process of groundwater by the recent freshwater through the structural lineaments within the study area. The predominance of sulphate anion concentration within Cl-sulphate group could be attributed to the depth and distance from the catchment area as well as the leaching processes of the evaporitic rock constituents. The hydrochemical parameters indicte a relative increase in the concentration of calcium, magnesium and sulphate ions which might indicate the influence of water-bearing formations of carbonates and evaporite sediments. The chemical analyses also indicated that the $\mathrm{Na}_{2} \mathrm{SO}_{4}$ is of deep percolation, while $\mathrm{NaHCO}_{3}$ is of surface and sallow meteoric water conditions.

\section{Acknowledgements}

The investigators would like to express their sincere appreciation to the United Arab Emirates University for the financial support of this study. The investigators would also like to express their gratitude to Mr. Hamdi Kandil for drafting Figure 1 of this manuscript.

\section{REFERENCES}

[1] H. S. Al Nuaimi, "Hydrogeological and Geophysical Studies on Al Jaww plain, Al Ain Area, United Arab Emirates," M.Sc Thesis, United Arab Emirates University, Al Ain, 2003, 159 p.

[2] M. E. Altoviski, "Dictionary for Hydrgeologist. Gosgeolitchizdat," USSR, Moscow, 1962, 616 p.

[3] M. C. Brook, "History \& Current Status of Municipal 
Wellfields in the Eastern Region of Abu Dhabi Emirate, 1979-2002," Environment Agency of Abu Dhabi (EAD), Abu Dhabi, Vol. 1 and 11, 2003.

[4] S. N. Davis and R. J. De Weist, "Hydrogeology," John Wiley and Sons, New York, 1966, 108 p.

[5] F. El-Shami, "The Hydrogeochemistry of the Spring of Ain Bu Sukhanah," U.A.E. Arab Gulf Journal of Scientific Research, Vol. 8, No. 1, 1990, pp. 34-36.

[6] Environment Agency, "Abu Dhabi Water Resources Statistics," Abu Dhabi (EAD), 2003.

[7] H. K. Garamoon, "Hydrogeological and Geomorphological Studies on the Abu Dhabi-Dubai-Al Ain Triangle, UAE," Unpublished Ph.D. Thesis, Geology Department, Faculty of Sciences, Ain Shames University, Cairo, 1996, $127 \mathrm{p}$.

[8] K. W. Glennie, M. G. A. Bouef, M. W. H. Clarke, M. M. Stuart, W. F. H. Pillar and B. M. Reinhardt, "Geology of the Oman Mountains," Transactions of the Royal Dutch Geological and Mining Society, Koninklijk Nederlands Geological Genootshap, 1974, pp. 31-423.

[9] A. A. Hamdan and H. S. Anan, "Cretaceous/Tertiary boundary in the United Arab Emirates," M.E.R.C, Ain Shams University, Earth Science Series, Vol. 7, 1993, pp. 223-231.

[10] A. A. Hamdan and S. A. Bahr, "Lithostratigraphy of the Paleogene Succession of Northern Jabal Hafit., Al-Ain Area, UAE," M.E.R.C., Earth Science Series, Ain Shams University, Vol. 6, 1992, pp. 201-224.

[11] A. A. Hamdan and W. Z. El-Deeb, "Stratigraphy of the Paleogene Succession of Jabal Malaqet, West of the Northern Oman Mountains," Fac. Sci., UAE University, Vol. 2, 1990, pp. 30-39.

[12] J. D. Hem, "Study and Interpretation of the Chemical Characteristics of Natural Water," 3rd Edition, Water-Supply Paper 2254, US Geological Survey, 1989.
[13] Hunting Geology and Geophysics Ltd., Report on Mineral Survey of the U.A.E., Al-Ain Area, Vol. 9, 1979, p 29.

[14] HydroConsult, "Reconnaissance Report and Development Proposals, Abu Dhabi, (UAE) Eastern Region Water Resources," Ministry of Petroleum and Mineral Resources Report, Government of Abu Dhabi, 1987, 126 p.

[15] G. N. Kamaneski, P. P. Klimintov and A. M. Ovitchinkov, "Hydrogeology of Ore Deposits," Gosgeolitchizdat, Moscow, USSR, 1953, $355 \mathrm{p}$.

[16] M. A. Khalifa, "Hydrogeology of the Geothermal Fractured Rock Well Field at Jabal Hafit, Abu Dhabi Emirate," Proceedings of the 3rd Gulf Water Confer, Muscat, 1997, pp. 125-140.

[17] M. A. Khalifa, "Geohydrology and the Source of Flowing Well Water in Al-Neima Area, Al, Abu Dhabi Emirate, UAE," National Drilling Company and United States Geological Survey, 2003, 9 p.

[18] G. Mathess, "The Properties of Groundwater," John Wiley and Sons, New York, 1982, pp. 215-255.

[19] Ministry of Agriculture and Fisheries, "Climatological Data," Vol. 3, 1979-1980 to 1991-1992, Department of Soil and Water, MAF, 1993, $442 \mathrm{p}$.

[20] A. M. Ovitchinkov, "General Hydrogeology," Gosgeolitchizdat Moscow, USSR, 1955, 383 p.

[21] A. M. Ovitchinkov, "Mineral Water: Gosgeolitchizdat," Moscow, USSR, 1963, $375 \mathrm{p}$.

[22] US Geological Survey (USGS) and United Arab Emirates National Drilling Company (NDC), "Ground Water Resources of Al Ain Area, Abu Dhabi Emirate," Unpublished Administrative Report 93-01, National Drilling Company, Abu Dhabi, 1993, 315 p.

[23] US Salinity Laboratory Staff, "Diagenesis and Improvement of Saline and Alkali Soils: US Dept. Adri.," Agricultural Handbook No. 60, 1954, pp. 60-160. 


\section{Appendix}

\begin{tabular}{|c|c|c|c|c|c|c|c|c|c|c|}
\hline \multirow[t]{2}{*}{ Serial No. } & \multirow[t]{2}{*}{ ID } & \multirow[t]{2}{*}{ TDS (ppm) } & \multirow[t]{2}{*}{ Units } & \multicolumn{7}{|c|}{ Chemical analysis represented as $\mathrm{mg} / \mathrm{l}, \mathrm{meq} / \mathrm{l}, \mathrm{meg} \%$} \\
\hline & & & & $\mathbf{K}^{+}$ & $\mathrm{Na}^{+}$ & $\mathrm{Ca}^{2+}$ & $\mathbf{M g}^{2+}$ & $\mathrm{Cl}^{-}$ & $\mathrm{SO}_{4}^{2-}$ & $\mathrm{HCO}_{3}^{-}$ \\
\hline & & 5740 & ppm & 465.0 & 1584.9 & 565.7 & 157.0 & 3089 & 495 & 111.8 \\
\hline \multirow[t]{3}{*}{1} & GW-1 & & meq/l & 11.89 & 68.94 & 28.23 & 12.92 & 87.13 & 10.31 & 1.83 \\
\hline & & & meq $\%$ & $10 \%$ & $57 \%$ & $23 \%$ & $11 \%$ & $88 \%$ & $10 \%$ & $2 \%$ \\
\hline & & 7520 & ppm & 77.6 & 2214.0 & 668.9 & 196.8 & 4130 & 841 & 120 \\
\hline \multirow[t]{3}{*}{2} & GW-2 & & meq/l & 1.98 & 96.3 & 33.38 & 16.19 & 116.49 & 17.52 & 1.97 \\
\hline & & & meq \% & $1 \%$ & $65 \%$ & $23 \%$ & $11 \%$ & $86 \%$ & $13 \%$ & $1 \%$ \\
\hline & & 6840 & ppm & 74.1 & 1933.0 & 673.9 & 176.1 & 4494 & 690.5 & 109.8 \\
\hline \multirow[t]{3}{*}{3} & GW-3 & & meq/l & 1.9 & 84.08 & 33.63 & 14.49 & 126.76 & 14.39 & 1.8 \\
\hline & & & meq $\%$ & $1 \%$ & $63 \%$ & $25 \%$ & $11 \%$ & $89 \%$ & $10 \%$ & $1 \%$ \\
\hline & & 6060 & ppm & 63.7 & 1677.9 & 600.3 & 142.3 & 3755 & 528.8 & 109.8 \\
\hline \multirow[t]{3}{*}{4} & GW-4 & & meq/l & 1.63 & 72.98 & 29.96 & 11.71 & 105.92 & 11.02 & 1.8 \\
\hline & & & meq \% & $1 \%$ & $63 \%$ & $26 \%$ & $10 \%$ & $89 \%$ & $9 \%$ & $2 \%$ \\
\hline & & 9770 & ppm & 97.2 & 2745.6 & 777.1 & 265.2 & 5480 & 1418 & 122 \\
\hline \multirow[t]{3}{*}{5} & GW-5 & & meq/l & 2.49 & 119.43 & 38.78 & 21.82 & 154.57 & 29.54 & 2 \\
\hline & & & meq \% & $1 \%$ & $65 \%$ & $21 \%$ & $12 \%$ & $83 \%$ & $16 \%$ & $1 \%$ \\
\hline & & 8450 & ppm & 80.9 & 2219.5 & 701.1 & 245.3 & 6212 & 1471 & 122 \\
\hline \multirow[t]{3}{*}{6} & GW-6 & & meq/l & 2.07 & 96.54 & 34.99 & 20.19 & 175.22 & 30.65 & 2 \\
\hline & & & meq \% & $1 \%$ & $63 \%$ & $23 \%$ & $13 \%$ & $84 \%$ & $15 \%$ & $1 \%$ \\
\hline & & 5020 & ppm & 71.6 & 1686.9 & 299.3 & 323.4 & 1811 & 3512 & 337.5 \\
\hline \multirow[t]{3}{*}{7} & GW-7 & & meq/l & 1.83 & 73.38 & 14.94 & 26.61 & 51.08 & 73.17 & 5.53 \\
\hline & & & meq \% & $2 \%$ & $63 \%$ & $13 \%$ & $23 \%$ & $39 \%$ & $56 \%$ & $4 \%$ \\
\hline & & 2050 & ppm & 26.3 & 477.5 & 150.9 & 232.7 & 444 & 1171 & 252.1 \\
\hline \multirow[t]{3}{*}{8} & GW-8 & & meq/l & 0.67 & 20.77 & 7.53 & 19.15 & 12.52 & 24.4 & 4.13 \\
\hline & & & meq \% & $1 \%$ & $43 \%$ & $16 \%$ & $40 \%$ & $30 \%$ & $59 \%$ & $10 \%$ \\
\hline & & 1910 & ppm & 29.8 & 515.6 & 155.4 & 258.6 & 430 & 1001 & 276.5 \\
\hline \multirow[t]{2}{*}{9} & GW-9 & & meq/l & 0.76 & 22.43 & 7.75 & 21.28 & 12.13 & 20.85 & 4.53 \\
\hline & & & meq\% & $1 \%$ & $43 \%$ & $15 \%$ & $41 \%$ & $32 \%$ & $56 \%$ & $12 \%$ \\
\hline
\end{tabular}


Continued

\begin{tabular}{|c|c|c|c|c|c|c|c|c|c|c|}
\hline & & 2280 & ppm & 25.7 & 424.5 & 123.3 & 219.9 & 558 & 1346 & 268.4 \\
\hline \multirow[t]{3}{*}{10} & GW-10 & & meq/l & 0.66 & 18.46 & 6.15 & 18.1 & 15.74 & 28.04 & 4.4 \\
\hline & & & meq\% & $2 \%$ & $43 \%$ & $14 \%$ & $42 \%$ & $33 \%$ & $58 \%$ & $9 \%$ \\
\hline & & 4240 & ppm & 49.0 & 1110.7 & 352.9 & 398.9 & 1192 & 2250 & 317.2 \\
\hline \multirow[t]{3}{*}{11} & GW-11 & & meq/l & 1.25 & 48.31 & 17.61 & 32.82 & 33.62 & 46.88 & 5.2 \\
\hline & & & meq\% & $1 \%$ & $48 \%$ & $18 \%$ & $33 \%$ & $39 \%$ & $55 \%$ & $6 \%$ \\
\hline & & 3790 & ppm & 48.3 & 914.7 & 351.3 & 392.0 & 976 & 2298 & 317.2 \\
\hline \multirow[t]{3}{*}{12} & GW-12 & & meq/l & 1.24 & 39.79 & 17.53 & 32.26 & 27.53 & 47.88 & 5.2 \\
\hline & & & meq\% & $1 \%$ & $44 \%$ & $19 \%$ & $36 \%$ & $34 \%$ & $59 \%$ & $6 \%$ \\
\hline & & 2530 & ppm & 28.3 & 480.4 & 150.4 & 239.3 & 615 & 1382 & 290.8 \\
\hline \multirow[t]{3}{*}{13} & GW-13 & & meq/l & 0.72 & 20.9 & 7.51 & 19.69 & 17.35 & 28.79 & 4.77 \\
\hline & & & meq\% & $1 \%$ & $43 \%$ & $15 \%$ & $40 \%$ & $34 \%$ & $57 \%$ & $9 \%$ \\
\hline & & 2250 & ppm & 32.7 & 588.8 & 203.6 & 276.7 & 492 & 1084 & 292.8 \\
\hline \multirow[t]{3}{*}{14} & GW-14 & & meq/l & 0.84 & 25.61 & 10.16 & 22.77 & 13.88 & 22.58 & 4.8 \\
\hline & & & meq\% & $1 \%$ & $43 \%$ & $17 \%$ & $38 \%$ & $34 \%$ & $55 \%$ & $12 \%$ \\
\hline & & 3080 & ppm & 389.0 & 726.4 & 261.7 & 329.7 & 492 & 1084 & 292.8 \\
\hline \multirow[t]{2}{*}{15} & GW-15 & & meq/l & 9.95 & 31.6 & 13.06 & 27.13 & 20.31 & 35.5 & 5 \\
\hline & & 13700 & ppm & 107.3 & 4113.9 & 988.0 & 427.9 & 7198 & 2315 & 154.5 \\
\hline \multirow[t]{3}{*}{16} & GW-16 & & meq/l & 2.74 & 178.94 & 49.3 & 35.21 & 203 & 48.2 & 2.53 \\
\hline & & & meq\% & $1 \%$ & $67 \%$ & $19 \%$ & $13 \%$ & $80 \%$ & $19 \%$ & $1 \%$ \\
\hline & & 6940 & ppm & 43.8 & 1685.0 & 522.3 & 191.2 & 3110 & 698 & 113.9 \\
\hline \multirow[t]{3}{*}{17} & GW-17 & & meq/l & 1.12 & 73.29 & 26.06 & 15.73 & 87.72 & 14.54 & 1.87 \\
\hline & & & meq\% & $1 \%$ & $63 \%$ & $22 \%$ & $14 \%$ & $84 \%$ & $14 \%$ & $2 \%$ \\
\hline & & 14800 & ppm & 105.5 & 4335.6 & 981.4 & 493.1 & 7130 & 2620 & 150.5 \\
\hline \multirow[t]{3}{*}{18} & GW-18 & & meq/l & 2.7 & 188.59 & 48.97 & 40.58 & 201.1 & 54.6 & 2.47 \\
\hline & & & meq\% & $1 \%$ & $67 \%$ & $17 \%$ & $14 \%$ & $78 \%$ & $21 \%$ & $1 \%$ \\
\hline & & 4050 & ppm & 42.1 & 1389.8 & 520.86 & 120.3 & 2416 & 498 & 113.9 \\
\hline \multirow[t]{3}{*}{19} & GW-19 & & meq/l & 1.08 & 60.45 & 25.99 & 9.9 & 68.15 & 10.38 & 1.87 \\
\hline & & & meq\% & $1 \%$ & $62 \%$ & $27 \%$ & $10 \%$ & $85 \%$ & $13 \%$ & $2 \%$ \\
\hline & & 7760 & ppm & 60.5 & 2110.0 & 665.4 & 213.3 & 3550 & 931 & 126.1 \\
\hline \multirow[t]{2}{*}{20} & GW-20 & & meq/l & 1.55 & 91.78 & 33.21 & 17.55 & 100.13 & 19.4 & 2.07 \\
\hline & & & meq\% & $1 \%$ & $64 \%$ & $23 \%$ & $12 \%$ & $82 \%$ & $16 \%$ & $2 \%$ \\
\hline
\end{tabular}




\section{Continued}

\begin{tabular}{|c|c|c|c|c|c|c|c|c|c|c|}
\hline & & 5780 & ppm & 59.6 & 1424.1 & 507.9 & 156.6 & 2975 & 571.5 & 101.7 \\
\hline \multirow[t]{3}{*}{21} & GW-21 & & meq/l & 1.52 & 61.94 & 25.35 & 12.89 & 83.91 & 11.91 & 1.67 \\
\hline & & & meq\% & $1 \%$ & $61 \%$ & $25 \%$ & $13 \%$ & $86 \%$ & $12 \%$ & $2 \%$ \\
\hline & & 5720 & ppm & 54.5 & 1432.0 & 497.8 & 150.5 & 2895 & 533.5 & 105.7 \\
\hline \multirow[t]{3}{*}{22} & GW-22 & & meq/l & 1.39 & 62.29 & 24.84 & 12.38 & 81.66 & 11.11 & 1.73 \\
\hline & & & meq\% & $1 \%$ & $62 \%$ & $25 \%$ & $12 \%$ & $86 \%$ & $12 \%$ & $2 \%$ \\
\hline & & 5720 & ppm & 54.5 & 1432.0 & 497.8 & 150.5 & 2895 & 533.5 & 105.7 \\
\hline \multirow[t]{3}{*}{23} & GW-23 & & meq/l & 1.56 & 63.69 & 27.19 & 12.64 & 75.45 & 11.33 & 1.87 \\
\hline & & & meq\% & $1 \%$ & $61 \%$ & $26 \%$ & $12 \%$ & $85 \%$ & $13 \%$ & $2 \%$ \\
\hline & & 5590 & ppm & 61.1 & 1464.2 & 544.9 & 153.6 & 2675 & 544 & 113.9 \\
\hline \multirow[t]{3}{*}{24} & GW-24 & & meq/l & 1.55 & 61.61 & 28.67 & 12.25 & 84.58 & 11.83 & 1.87 \\
\hline & & & meq\% & $1 \%$ & $59 \%$ & $28 \%$ & $12 \%$ & $86 \%$ & $12 \%$ & $2 \%$ \\
\hline & & 5330 & ppm & 60.5 & 1416.4 & 574.6 & 148.9 & 2998.5 & 568 & 113.9 \\
\hline \multirow[t]{3}{*}{25} & GW-25 & & meq/l & 1.65 & 5.99 & 29.16 & 11.82 & 79.82 & 11.6 & 1.87 \\
\hline & & & meq\% & $3 \%$ & $12 \%$ & $60 \%$ & $24 \%$ & $86 \%$ & $12 \%$ & $2 \%$ \\
\hline & & 5970 & ppm & 61.4 & 1607.1 & 618.2 & 158.7 & 2830 & 557 & 113.9 \\
\hline \multirow[t]{3}{*}{26} & GW-26 & & meq/l & 1.57 & 69.91 & 30.85 & 13.06 & 84.55 & 13.2 & 1.87 \\
\hline & & & meq\% & $1 \%$ & $61 \%$ & $27 \%$ & $11 \%$ & $85 \%$ & $13 \%$ & $2 \%$ \\
\hline & & 6450 & ppm & 68.3 & 1706.0 & 627.5 & 187.2 & 3205 & 705 & 122 \\
\hline \multirow[t]{3}{*}{27} & GW-27 & & meq/l & 1.75 & 74.21 & 31.31 & 15.4 & 90.4 & 14.7 & 2 \\
\hline & & & meq\% & $1 \%$ & $60 \%$ & $26 \%$ & $13 \%$ & $84 \%$ & $14 \%$ & $2 \%$ \\
\hline & & 4520 & ppm & 51.7 & 1009.5 & 439.1 & 587.0 & 1003 & 3371 & 378.2 \\
\hline \multirow[t]{3}{*}{28} & GW-28 & & meq/l & 1.32 & 43.91 & 21.91 & 48.3 & 28.29 & 70.23 & 6.2 \\
\hline & & & meq\% & $1 \%$ & $38 \%$ & $19 \%$ & $42 \%$ & $27 \%$ & $67 \%$ & $6 \%$ \\
\hline & & 3850 & ppm & 48.0 & 839.6 & 324.3 & 434.1 & 1003 & 3371 & 378.2 \\
\hline \multirow[t]{3}{*}{29} & GW-29 & & meq/l & 1.23 & 36.52 & 16.18 & 35.72 & 23.83 & 58.52 & 5.53 \\
\hline & & & meq\% & $1 \%$ & $41 \%$ & $18 \%$ & $40 \%$ & $27 \%$ & $67 \%$ & $6 \%$ \\
\hline & & 5090 & ppm & 61.5 & 1196.9 & 479.8 & 588.0 & 1305 & 4190 & 325.3 \\
\hline \multirow[t]{2}{*}{30} & GW-30 & & meq/l & 1.57 & 52.06 & 23.94 & 48.39 & 36.81 & 87.29 & 5.33 \\
\hline & & & meq\% & $1 \%$ & $41 \%$ & $19 \%$ & $38 \%$ & $28 \%$ & $67 \%$ & $4 \%$ \\
\hline
\end{tabular}




\section{Continued}

\begin{tabular}{|c|c|c|c|c|c|c|c|c|c|c|}
\hline & & 2160 & ppm & 32.8 & 386.5 & 250.8 & 250.6 & 500 & 1835 & 260.3 \\
\hline \multirow[t]{3}{*}{31} & GW-31 & & meq/l & 0.84 & 16.81 & 12.52 & 20.62 & 14.1 & 38.23 & 4.27 \\
\hline & & & meq\% & $2 \%$ & $33 \%$ & $25 \%$ & $41 \%$ & $25 \%$ & $68 \%$ & $8 \%$ \\
\hline & & 4340 & ppm & 51.9 & 858.2 & 367.7 & 476.4 & 900 & 2810 & 317.2 \\
\hline \multirow[t]{3}{*}{32} & GW-32 & & meq/l & 1.33 & 37.33 & 18.35 & 39.2 & 25.39 & 58.54 & 5.2 \\
\hline & & & meq\% & $1 \%$ & $39 \%$ & $19 \%$ & $41 \%$ & $28 \%$ & $66 \%$ & $6 \%$ \\
\hline & & 8470 & ppm & 63.2 & 2275.4 & 866.5 & 269.8 & 4999 & 1712 & 235.9 \\
\hline \multirow[t]{3}{*}{33} & GW-33 & & meq/l & 1.62 & 98.97 & 43.24 & 22.2 & 141 & 35.6 & 3.87 \\
\hline & & & meq \% & $1 \%$ & $60 \%$ & $26 \%$ & $13 \%$ & $78 \%$ & $20 \%$ & $2 \%$ \\
\hline & & 17400 & ppm & 179.5 & 4927.3 & 1812.8 & 673.7 & 9420 & 1746 & 142.3 \\
\hline \multirow[t]{3}{*}{34} & GW-34 & & meq/l & 4.59 & 214.33 & 90.46 & 55.44 & 265.71 & 36.38 & 2.33 \\
\hline & & & meq\% & $1 \%$ & $59 \%$ & $25 \%$ & $15 \%$ & $87 \%$ & $12 \%$ & $1 \%$ \\
\hline & & 7490 & ppm & 124.9 & 3824.8 & 1764.4 & 443.8 & 3140 & 6280 & 122 \\
\hline \multirow[t]{3}{*}{35} & GW-35 & & meq/l & 3.19 & 166.37 & 88.05 & 36.52 & 88.57 & 131 & 2 \\
\hline & & & meq\% & $1 \%$ & $57 \%$ & $30 \%$ & $12 \%$ & $40 \%$ & $59 \%$ & $1 \%$ \\
\hline & & 15200 & ppm & 131.3 & 4116.0 & 1650.9 & 543.5 & 9995 & 1415 & 211.5 \\
\hline \multirow[t]{3}{*}{36} & GW-36 & & meq/l & 3.36 & 179.04 & 82.38 & 44.72 & 281.9 & 282 & 3.47 \\
\hline & & & meq \% & $1 \%$ & $58 \%$ & $27 \%$ & $14 \%$ & $50 \%$ & $50 \%$ & $1 \%$ \\
\hline & & 12300 & ppm & 115.1 & 3698.2 & 1318.3 & 434.9 & 4970 & 1960 & 93.53 \\
\hline \multirow[t]{3}{*}{37} & GW-37 & & meq/l & 2.94 & 160.86 & 65.79 & 35.79 & 140.19 & 40.83 & 1.53 \\
\hline & & & meq\% & $1 \%$ & $61 \%$ & $25 \%$ & $13 \%$ & $77 \%$ & $22 \%$ & $1 \%$ \\
\hline & & 17200 & ppm & 1656.8 & 4953.5 & 1676.3 & 5172.8 & 10000 & 1930 & 207.4 \\
\hline \multirow[t]{3}{*}{38} & GW-38 & & meq/l & 42.38 & 215.47 & 83.65 & 425.66 & 282.07 & 40.21 & 3.4 \\
\hline & & & meq\% & $6 \%$ & $28 \%$ & $11 \%$ & $55 \%$ & $87 \%$ & $12 \%$ & $1 \%$ \\
\hline & & 13700 & ppm & 131.6 & 4218.0 & 1502.0 & 4829.1 & 7798 & 1687 & 178.9 \\
\hline \multirow[t]{3}{*}{39} & GW-39 & & meq/l & 3.37 & 183.47 & 74.95 & 397.38 & 219.96 & 35.15 & 2.93 \\
\hline & & & meq\% & $1 \%$ & $28 \%$ & $11 \%$ & $60 \%$ & $85 \%$ & $14 \%$ & $1 \%$ \\
\hline & & 7110 & ppm & 79.0 & 2633.8 & 300.9 & 364.4 & 2385 & 3990 & 353.8 \\
\hline \multirow[t]{2}{*}{40} & GW-40 & & meq/l & 2.02 & 114.56 & 15.02 & 29.99 & 67.27 & 83.13 & 5.8 \\
\hline & & & meq\% & $1 \%$ & $71 \%$ & $9 \%$ & $19 \%$ & $43 \%$ & $53 \%$ & $4 \%$ \\
\hline
\end{tabular}


Continued

\begin{tabular}{|c|c|c|c|c|c|c|c|c|c|c|}
\hline & & 7470 & ppm & 99.1 & 2114.2 & 968.9 & 247.2 & 4485 & 825 & 89.47 \\
\hline \multirow[t]{3}{*}{41} & GW-41 & & meq/l & 2.53 & 91.96 & 48.35 & 20.34 & 126.51 & 17.19 & 1.47 \\
\hline & & & meq \% & $2 \%$ & $56 \%$ & $30 \%$ & $12 \%$ & $87 \%$ & $12 \%$ & $1 \%$ \\
\hline & & 7460 & ppm & 97.2 & 2129.3 & 970.8 & 251.1 & 4010 & 911 & 105.7 \\
\hline \multirow[t]{3}{*}{42} & GW-42 & & meq/l & 2.49 & 92.62 & 48.45 & 20.66 & 113.11 & 18.98 & 1.73 \\
\hline & & & meq\% & $2 \%$ & $56 \%$ & $30 \%$ & $13 \%$ & $85 \%$ & $14 \%$ & $1 \%$ \\
\hline & & 8810 & ppm & 122.3 & 2822.7 & 942.0 & 325.3 & 4610 & 2130 & 183 \\
\hline \multirow[t]{3}{*}{43} & GW-43 & & meq/l & 3.13 & 122.78 & 47.01 & 26.77 & 130.03 & 44.38 & 3 \\
\hline & & & meq $\%$ & $2 \%$ & $61 \%$ & $24 \%$ & $13 \%$ & $73 \%$ & $25 \%$ & $2 \%$ \\
\hline & & 7490 & ppm & 97.8 & 2192.9 & 900.7 & 266.7 & 3500 & 1750 & 187.1 \\
\hline \multirow[t]{3}{*}{44} & GW-44 & & meq/l & 2.5 & 95.39 & 44.95 & 21.95 & 98.72 & 36.5 & 3.07 \\
\hline & & & meq\% & $2 \%$ & $58 \%$ & $27 \%$ & $13 \%$ & $71 \%$ & $26 \%$ & $2 \%$ \\
\hline & & 8090 & ppm & 96.9 & 2322.3 & 877.2 & 284.7 & 4580 & 1420 & 65.07 \\
\hline \multirow[t]{3}{*}{45} & GW-45 & & meq/l & 2.48 & 101.01 & 43.77 & 23.43 & 129.2 & 29.6 & 1.07 \\
\hline & & & meq\% & $1 \%$ & $59 \%$ & $26 \%$ & $14 \%$ & $81 \%$ & $19 \%$ & $1 \%$ \\
\hline & & 3210 & ppm & 79.4 & 1123.5 & 131.8 & 187.4 & 1130 & 2430 & 471.7 \\
\hline \multirow[t]{3}{*}{46} & GW-46 & & meq/l & 2.03 & 48.87 & 6.58 & 15.42 & 31.87 & 50.63 & 7.73 \\
\hline & & & meq\% & $3 \%$ & $67 \%$ & $9 \%$ & $21 \%$ & $35 \%$ & $56 \%$ & $9 \%$ \\
\hline & & 2760 & ppm & 67.6 & 879.8 & 110.7 & 190.9 & 860 & 940 & 520.5 \\
\hline \multirow[t]{3}{*}{47} & GW-47 & & meq/l & 1.73 & 38.27 & 5.52 & 15.71 & 24.26 & 19.58 & 8.53 \\
\hline & & & meq\% & $3 \%$ & $63 \%$ & $9 \%$ & $26 \%$ & $46 \%$ & $37 \%$ & $16 \%$ \\
\hline & & 6770 & ppm & 89.6 & 1846.4 & 840.0 & 213.0 & 3715 & 770 & 105.7 \\
\hline \multirow[t]{3}{*}{48} & GW-48 & & meq/l & 2.29 & 80.31 & 41.92 & 17.53 & 104.79 & 16.04 & 1.73 \\
\hline & & & meq \% & $2 \%$ & $57 \%$ & $30 \%$ & $12 \%$ & $86 \%$ & $13 \%$ & $1 \%$ \\
\hline & & 7070 & ppm & 87.5 & 1826.5 & 842.4 & 218.2 & 3725 & 825 & 105.7 \\
\hline \multirow[t]{3}{*}{49} & GW-49 & & meq/l & 2.24 & 79.45 & 42.04 & 17.96 & 105.07 & 17.19 & 1.73 \\
\hline & & & meq \% & $2 \%$ & $56 \%$ & $30 \%$ & $13 \%$ & $85 \%$ & $14 \%$ & $1 \%$ \\
\hline & & 8000 & ppm & 107.9 & 2405.0 & 668.8 & 338.7 & 3150 & 1815 & 248.1 \\
\hline \multirow[t]{2}{*}{50} & GW-50 & & meq/l & 2.76 & 104.61 & 33.37 & 27.87 & 88.85 & 37.81 & 4.07 \\
\hline & & & meq\% & $2 \%$ & $62 \%$ & $20 \%$ & $17 \%$ & $68 \%$ & $29 \%$ & $3 \%$ \\
\hline
\end{tabular}




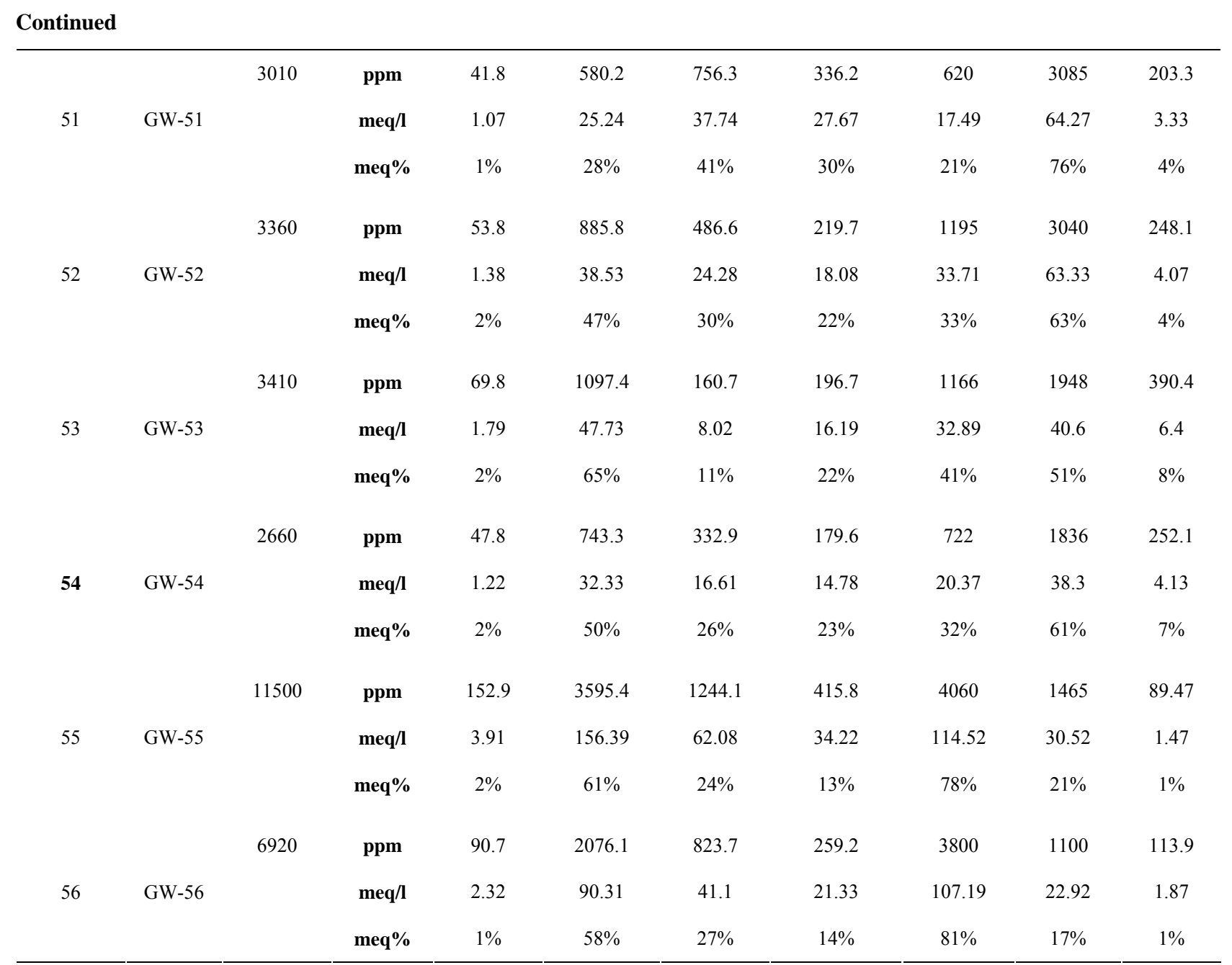

